\title{
Potential Use of Organic- and Hard-Rock Mine Wastes on Aided Phytostabilization of Large-Scale Mine Tailings under Semiarid Mediterranean Climatic Conditions: Short-Term Field Study
}

\author{
Claudia Santibañez, ${ }^{1,2}$ Luz María de la Fuente, ${ }^{2}$ Elena Bustamante, ${ }^{2}$ Sergio Silva, ${ }^{3}$ Pedro \\ León-Lobos, ${ }^{3}$ and Rosanna Ginocchio ${ }^{2}$ \\ ${ }^{1}$ Facultad de Ciencias Silvoagropecuarias, Universidad Mayor, Camino La Pirámide 5750, Huechuraba, Santiago, Chile \\ ${ }^{2}$ Unidad de Fitotoxicidad y Fitorremediación, Centro de Investigación Minera y Metalúrgica, Avenida Parque Antonio Rabat 6500, \\ Vitacura 7660045, Santiago, Chile \\ ${ }^{3}$ Instituto de Investigaciones Agropecuarias, CRI Intihuasi, Colina San Joaquin s/n, La Serena, Chile
}

Correspondence should be addressed to Rosanna Ginocchio, rginocc@cimm.cl

Received 23 February 2011; Revised 2 June 2011; Accepted 10 June 2011

Academic Editor: Maria Fernández Sanjurjo

Copyright (c) 2012 Claudia Santibañez et al. This is an open access article distributed under the Creative Commons Attribution License, which permits unrestricted use, distribution, and reproduction in any medium, provided the original work is properly cited.

The study evaluated the efficacy of organic- and hard-rock mine waste type materials on aided phytostabilization of Cu mine tailings under semiarid Mediterranean conditions in order to promote integrated waste management practices at local levels and to rehabilitate large-scale (from 300 to 3,000 ha) postoperative tailings storage facilities (TSFs). A field trial with 13 treatments was established on a TSF to test the efficacy of six waste-type locally available amendments (grape and olive residues, biosolids, goat manure, sediments from irrigation canals, and rubble from $\mathrm{Cu}$-oxide lixiviation piles) during early phases of site rehabilitation. Results showed that, even though an interesting range of waste-type materials were tested, biosolids (100 tha ${ }^{-1}$ dry weight, d.w.) and grape residues $\left(200 \mathrm{tha}^{-1} \mathrm{~d}\right.$.w.), either alone or mixed, were the most suitable organic amendments when incorporated into tailings to a depth of $20 \mathrm{~cm}$. Incorporation of both rubble from $\mathrm{Cu}$-oxide lixiviation piles and goat manure into upper tailings also had effective results. All these treatments improved chemical and microbiological properties of tailings and lead to a significant increase in plant yield after three years from trial establishment. Longer-term evaluations are, however required to evaluate self sustainability of created systems without further incorporation of amendments.

\section{Introduction}

Copper mining operations may adversely affect the environment due to deposition of large volumes of a number of hard-rock waste materials in nearby areas, such as sterile rocks, smelter slags, smelter dust, and tailings, among others. When sulfide copper ores are concentrated by flotation, approximately $80 \%$ of total wastes are tailings, which still contain a concentration of metals (i.e., $\mathrm{Cu}, \mathrm{Zn}, \mathrm{Mo}, \mathrm{Ni}, \mathrm{Pb}$, Cd) and metalloids (i.e., As) that may pose environmental risks after inadequate deposition and management [1-6].

Currently, tailings are deposited in artificial dumps, or tailings storage facilities (TSFs), where fine solid particles (tailing sands) are separated from water by gravity
[7]. Abandonment of postoperative TSFs under semiarid Mediterranean climatic conditions, such as in north-central Chile, led to complete water evaporation from upper tailings [7]. Without proper closure management, this fine, homogenous, and noncohesive material is left exposed to physical and chemical environmental forces [1,8], causing erosion by wind. Deposition of metal/metalloid-rich tailings into nearby soils and surface waters may pose risks to human health, agricultural activities, and wildlife [3, 9, 10]. Depending on tailings mineralogy (i.e., content of indigenous iron-/sulfur-oxidizing bacteria [11, 12]), and geographic location, acid mine drainage and lixiviation of metals may also occur with some secondary environmental impacts on surface and ground waters [7]. 
After a long period since abandonment, postoperative TSFs are generally devoid of vegetation or covered with a rather scarce vegetation cover [13-15]. Spontaneous plant colonization of TSFs is a very slow process as mine tailings are usually characterized by bad drainage, compactation, absence of organic matter and nitrogen, neutral to low $\mathrm{pH}[7$, $14,16]$, and limited soil-type microbiota to make energy and nutrients of litter available to plants [10]. Additionally, under semiarid climatic conditions, these problems are exacerbated by the builtup of salinity, as a high proportion of rainfall and the water contained in TSFs undergo evaporation rather than infiltration $[7,13]$. Therefore, physical and chemical characteristics of mine tailings, among other factors, interact to almost completely suppress seed germination, plant growth, and microbial activity $[10,17]$.

Aided phytostabilization is recognized as a potentially cost-effective and ecologically sound approach to containment of metal-polluted soils and mine tailings $[5,15,18$ 20]. Their primary objectives are to reduce the mobility, ecotoxicity, and dispersion of metals/metalloids through the environment $[5,15,19,20]$. This technique requires both incorporation of adequate inorganic and/or organic amendments to topsoils and revegetation with adequate plant species (i.e., metal tolerant plants, likely with an excluder phenotype) for immobilizing metals/metalloids in the rhizospheric zone and providing erosion control and wildlife habitat $[2-5,5-22]$. Use of native plants is a focus of this technology because they often demonstrate tolerance to local environmental conditions and provide a foundation for natural ecological succession. However, success of aided phytostabilization on mine tailings also depends on the rapid improvement of most, if not all, limiting physical and chemical factors of the substrate for proper plant establishment and growth, including the establishment of proper soil microbial activity [16, 23-25]. Microbial activity is fundamental for the biochemical cycling of carbon, nitrogen, and phosphorus and the processes of organic matter turnover [26], and thus for achieving self-sustainable ecosystems [27].

Establishment of a vegetation cover helps to control erosion and provide organic matter in the substrate, increasing substrate aggregation and sequestration of pollutants $[5,15]$. Most of these functions can be induced through proper application of amendments into mine tailings, such as organic and/or inorganic materials. In general, inorganic amendments improve either physical characteristics of tailings, such as compactation and drainage, or some limited chemical characteristics, such as $\mathrm{pH}$ and excessive soluble metal levels $[25,28-30]$. Organic amendments improve physical characteristics of tailings, mitigate their metal toxicity, inoculate them with soil microorganisms, and incorporate required macronutrients and organic matter $[5,15,25,27,28,31-33]$.

Even though aided phytostabilization has been effectively used on metal-enriched soils and hard-rock mine wasted, such as TSFs, particularly in temperate areas (i.e., $[10,23,24,34,35])$, its use on postoperative TSFs of northcentral Chile represent a new challenge. On one hand, postoperative TSFs being generated by large-scale copper mine operations in Chile have larger surface areas than the ones generated in other mining countries (range of 300 to $3,000 \mathrm{ha}$ ); therefore, local availability of very large amounts of proper amendments is by far a more limiting aspect for application of the technology than in other copper mining countries. This represents an opportunity for generating alternative disposal areas for other massive wastes that cannot be largely applied on croplands (i.e., agrowastes, biosolids, hard-rock mine wastes); however, their efficacy to improve physical, chemical, and biological properties of tailings have to be evaluated. On the other hand, experiences of aided phytostabilization on TSFs mainly gained in temperate climates (i.e., Canada) may not be directly applied to TSFs located in semiarid regions, such as north-central Chile. For example, organic covers (approx. $50 \mathrm{~cm}$ depth) made with biosolids and/or other organic wastes generated by cellulose-producing plants or agricultural activities have been effectively used on aided phytostabilization programs on TSFs in temperate areas (i.e., $[10,23,24,34,35]$ ), but they are inadequate under Mediterranean semiarid climate type conditions as salinization of organic covers strongly limit plant establishment and growth (i.e., $[5,25,36$, 37]). Therefore, alternative management options, such as incorporation into upper tailings, have to be evaluated.

The main objective of the present study was to assess the efficacy of a range of locally available organic and hardrock mine waste-type materials on aided phytostabilization of postoperative copper TSFs under semiarid Mediterranean climate type conditions, with emphasis on chemical and biological parameters. The use of locally available wastes as tailing amendments, through promotion of integrated waste management practices at local level, was prioritized in order to achieve the large volumes that will be required by the largescale copper mine operations in north-central Chile. Plant yield, metal uptake and translocation to aerial tissues, and the evolution of a number of microbiological and chemical parameters of the substrate were assessed.

\section{Materials and Methods}

2.1. Study Site. The study was conducted at La Cocinera TSF (6.7 ha; 6.618.700 N-291.300 E) owned by the Ovalle copper mining plant of ENAMI. This postoperative and dried TSF is located in north-central Chile, Coquimbo Region, in an area under semiarid Mediterranean climate type conditions. Annual rainfall in the area averages $237 \mathrm{~mm}$, concentrated during April to September (Autumn-Winter). The dry season extends from October to May. During this period the water balance is negative, resulting in a soil moisture deficit. Mean temperature of the warmest month (January) and the coldest month (July) are $23^{\circ} \mathrm{C}$ and $7^{\circ} \mathrm{C}$, respectively [36].

Tailings of La Cocinera TSF are characterized by a clay loam texture, slightly alkaline $\mathrm{pH}$ (7.98), elevated electric conductivity (EC, $5.62 \mathrm{mS} \mathrm{m}^{-1}$ ), very low organic matter $(0.48 \%)$ and available N-P contents, low cationexchange capacity (CEC, $6.28 \mathrm{meq} 100 \mathrm{mg}^{-1}$ ), and very high concentrations of sulphate $\left(2,912 \mathrm{mg} \mathrm{L}^{-1}\right)$, total copper $\left(4,393 \mathrm{mg} \mathrm{kg}^{-1}\right.$, dry weight basis (d.w.)), total zinc 
TABLE 1: Experimental treatments and description of amendments and doses used on the field trial established at La Cocinera tailings storage facility, north-central Chile.

\begin{tabular}{|c|c|c|}
\hline Treatment & Amendment & Dose \\
\hline Control, C & - & - \\
\hline \multirow{2}{*}{$\mathrm{RM}$} & Rubble from lixiviation piles & $1000 \mathrm{tha}^{-1}$ \\
\hline & Manure (goat) & $108 \mathrm{tha}^{-1}$ \\
\hline \multirow{3}{*}{ RMS } & Rubble & $1000 \mathrm{tha}^{-1}$ \\
\hline & Manure & $108 \mathrm{tha}^{-1}$ \\
\hline & Sediment of irrigation canals & Layer of $5 \mathrm{~cm}$ \\
\hline B1 & Biosolids & $100 \mathrm{tha}^{-1}$ \\
\hline B2 & Biosolids & $200 \mathrm{tha}^{-1}$ \\
\hline G1 & Grape residues & $89 \mathrm{tha}^{-1}$ \\
\hline G2 & Grape residues & $200 \mathrm{tha}^{-1}$ \\
\hline $\mathrm{O} 1$ & Olive residues & $91 \mathrm{tha}^{-1}$ \\
\hline $\mathrm{O} 2$ & Olive residues & $200 \mathrm{tha}^{-1}$ \\
\hline \multirow{2}{*}{ GB } & Grape residues & $131 \mathrm{tha}^{-1}$ \\
\hline & Biosolids & $20 \mathrm{tha}^{-1}$ \\
\hline \multirow{2}{*}{ GM } & Grape residues & $91 \mathrm{tha}^{-1}$ \\
\hline & Manure & $70 \mathrm{tha}^{-1}$ \\
\hline \multirow{2}{*}{ OB } & Olive residues & $135 \mathrm{tha}^{-1}$ \\
\hline & Biosolids & $19 \mathrm{tha}^{-1}$ \\
\hline \multirow{2}{*}{$\mathrm{OM}$} & Olive residues & $96 \mathrm{tha}^{-1}$ \\
\hline & Manure & $67 \mathrm{tha}^{-1}$ \\
\hline
\end{tabular}

(1,619 $\mathrm{mg} \mathrm{kg}^{-1}$ d.w.), total iron $\left(87,094 \mathrm{mg} \mathrm{kg}^{-1}\right.$ d.w.), and total calcium $\left(35,504 \mathrm{mg} \mathrm{kg}^{-1}\right.$ d.w.; [15]). The existing literature $[38,39]$ describes the local soils as clay loam in texture, from colluvial and alluvial origin, neither saline (EC of $2.29 \mathrm{mS} \mathrm{m}^{-1}$ ) nor sodic, with organic matter content around $1.5-2.8 \%$, pH of 7.42, and CEC of $13.27 \mathrm{meq} 100 \mathrm{mg}^{-1}$. Even though, some physical and chemical characteristics of study tailings are similar to local soils, such as texture and $\mathrm{pH}$, most of the others need to be improved in order to support a native plant cover. Therefore, the main emphasis of the present study was to evaluate the efficacy of selected amendments to improve limiting chemical and biological parameters of tailings.

2.2. Experimental Design. A $2,400 \mathrm{~m}^{2}$ field trial $(60 \mathrm{~m}$ long $\times 40 \mathrm{~m}$ wide) was conducted at La Cocinera TSF to evaluate some biological and chemical endpoints of mine tailings amended with several local available organic and inorganic residues for a total of 12 treatment plots and a control (no amended tailings) plot (Table 1); each treatment was replicated three times. Selected amendments were discarded rubble from $\mathrm{Cu}$-oxide lixiviation piles $(\mathrm{R})$, available at the same mine operation; goat manure (M) from nearby cattle yards; sediments from the cleaning process of local irrigation canals (S); air-dried biosolids (B) from a municipal water treatment plant; solid pressing grape residues $(\mathrm{G})$ from a spirit (pisco) producing plant; solid olive mill residues (O) from an olive oil producing plant. General properties of selected amendments are given in Table 2, and details (amendment types and doses) of experimental treatments are shown in Table 1. Application rates of organic residues were either decided according to available information in the literature for hard-rock wastes or metal-polluted degraded soils, when added alone (i.e., [40]), or with a target of 5\% $\mathrm{OM}$ and a $\mathrm{C}: \mathrm{N}$ ratio of 30 in amended tailings when added in mixtures of C-rich (i.e., grape residues, olive residues) and $\mathrm{N}$-rich organic residues (i.e., biosolids, manure (i.e., [24])). Application rate of discarded rubble from $\mathrm{Cu}$-oxide lixiviation piles was decided with a preliminary laboratory evaluation to change tailings texture from loam, to sandy loam while sediments from irrigation canals were used according to their availability. Amendments were mixed on the upper layer of tailings $(0-20 \mathrm{~cm}$ depth) with a gasoline-operated rototiller, to avoid salinization problems in amended tailings; the exception was sediment from irrigation canals which were applied on top of tailings, as we considered them equivalent to preserved topsoils used as top covers on mine rehabilitation (i.e., $[1,13]$ ). The experimental layout was a complete randomized block design.

On March 2006, each experimental plot $(5 \times 5 \mathrm{~m})$ was first amended and then seeded with $800 \mathrm{~g}$ of perennial ryegrass (Lolium perenne var Nui) and $38 \mathrm{~g}$ of a mixture of local grasses/herbs previously collected from either nearby wild areas and from a grass population (Polypogon australis) spontaneously established in a restricted area of the same TSF, following the methodology of Gold et al. [41]. This represents a seeding rate of $335 \mathrm{~kg} \mathrm{ha}^{-1}$, a value higher than the range of 20 to $120 \mathrm{~kg} \mathrm{ha}^{-1}$ recommended for remediation of metal-contaminated soils of hard-rock wastes (i.e., [4244]), but conservative considering that no information about metal tolerance of the species was available. The study area was wire-mesh fenced, and all grazing from domestic and wild herbivores was excluded; wind-breakers were built in two sides of the perimeter in order to reduce wind erosion. An irrigation system was established in the site with spray sprinklers located in the center of every experimental plot to assure plant establishment and development in the early stages. Irrigation was kept from March to November, during three consecutive years (2006 to 2008), to complement natural winter precipitations; irrigation water was obtained from a nearby stream.

2.3. Substrate Sampling and Analysis. Substrate samples were collected from all experimental plots at the time of addition of amendments (March 2006) and after two (March 2008) years, using a manual stainless steel soil auger. Each plot sample consisted of two bulked subsamples $\left(25 \mathrm{~cm}^{3}\right.$ cores $)$ randomly collected at $0-20 \mathrm{~cm}$ depth. A composite sample was made from mixing both subsamples which were placed in a hermetically sealed plastic bags, homogenized in the field at collection time, and stored at $4{ }^{\circ} \mathrm{C}$ in the dark until their transportation to the laboratory. Roots were manually removed from all samples prior analyses and processing in the laboratory. Plot samples were divided into two aliquots; one was used for microbial analyses, and the other was used for chemical characterization as described below. 
TABLE 2: General properties of selected organic and inorganic amendments for aided phytostabilization of Cu-sulfidic tailings under semiarid Mediterranean climate conditions.

\begin{tabular}{|c|c|c|c|c|c|c|c|c|c|c|c|c|c|}
\hline \multirow{2}{*}{ Amendment } & \multirow{2}{*}{$\begin{array}{l}\text { Bulk density } \\
(\mathrm{g} / \mathrm{mL})\end{array}$} & \multirow{2}{*}{$\begin{array}{c}\mathrm{pH} \\
\text { (water) }\end{array}$} & \multirow{2}{*}{$\begin{array}{l}\text { SOC } \\
(\%)\end{array}$} & \multirow{2}{*}{$\begin{array}{c}\mathrm{EC} \\
(\mathrm{mS} / \mathrm{cm})\end{array}$} & \multirow{2}{*}{$\begin{array}{l}\text { Sulphate } \\
(\mathrm{mg} / \mathrm{L})\end{array}$} & \multicolumn{3}{|c|}{ Total metal $(\mathrm{mg} / \mathrm{kg})$} & \multirow{2}{*}{$\begin{array}{l}\text { Total P } \\
(\mathrm{mg} / \mathrm{kg})\end{array}$} & \multirow{2}{*}{$\begin{array}{l}\text { Total K } \\
(\mathrm{mg} / \mathrm{kg})\end{array}$} & \multirow{2}{*}{$\begin{array}{c}\text { Total } \mathrm{N} \\
(\%)\end{array}$} & \multirow{2}{*}{$\begin{array}{c}\text { Total C } \\
(\%)\end{array}$} & \multirow{2}{*}{$C: N$} \\
\hline & & & & & & $\mathrm{Cu}$ & $\mathrm{Zn}$ & $\mathrm{Fe}$ & & & & & \\
\hline Biosolids (B) & 0.36 & 6.20 & 81 & 7.04 & 600 & 483 & 525 & 5493 & 9780 & 6638 & 7.4 & 46.9 & 6.3 \\
\hline Grape residues $(\mathrm{G})$ & 0.45 & 5.64 & 94 & 1.94 & 201 & 31 & 21 & 937 & 2800 & 24500 & 2.9 & 56.8 & 19.6 \\
\hline Olive residues $(\mathrm{O})$ & 0.41 & 5.71 & 95 & 2.91 & 1.25 & 16 & 11 & 2076 & 800 & 10500 & 1.0 & 54.3 & 53.8 \\
\hline Goat Manure (M) & 0.32 & 7.92 & 71 & 12.18 & 642 & 46 & 58 & 8517 & 4100 & 29700 & 2.5 & 40.1 & 16.2 \\
\hline Sediments (S) & 1.12 & 6.91 & 0.36 & 4.20 & 1386 & 333 & 177 & n.d. & 700 & 3400 & 0.12 & 0.02 & 0.2 \\
\hline Rubble (R) & 1.70 & 5.28 & 0.23 & 5.55 & 3454 & 7412 & 510 & n.d. & 1300 & 1500 & 0.01 & 0.32 & 32.0 \\
\hline
\end{tabular}

2.3.1. Substrate Analysis (Bulk and Pore Water). Composite samples were made mixing replicated plots for each experimental treatment, as substrates underwent several analyses (bulk, pore water, field capacity at $100 \%$, etc.). Substrate samples were air dried and sieved $(<2 \mathrm{~mm})$ before analytical determinations. The total percentage of the sample corresponding to the soil whose particle size was greater than $2 \mathrm{~mm}$ was registered (retained by the sieve), and the fraction less than $2 \mathrm{~mm}$ was determined by granulometry using the method of Bouyoucos [40]. The $\mathrm{pH}$ and electrical conductivity (EC) were measured in a $1: 1$ substrate to water solution using a glass electrode. Soil organic carbon (SOC) was determined by the Walkey and Black wet dichromate oxidation method [40]. Cation exchange capacity (CEC) and total $\mathrm{N}$ and $\mathrm{Cu}$ were determined according to protocols of the USDA [40] and US EPA [45], respectively. In the case of total $\mathrm{Cu}$ determinations in bulk substrate samples, every digestion batch included one blank sample, one standard reference material (SRM) sample (Loam-B, catalog CRM-LO-B; High-Purity Standard, Charleston, SC, USA), one duplicate sample, and one quality-control sample for the quality-assurance and quality-control criteria. Digested samples were analyzed for total $\mathrm{Cu}$ contents by flame atomic absorption spectrometry (FAAS, AAnalyst 300; PerkinElmer). Background nonatomic absorption was corrected with a deuterium continuous lamp. The atomic absorption analytical device was housed in a class 1000 clean-room laboratory, and the loading of the autosampler tray was done in a class 100 laminar flow cabinet. The calibration standard was prepared with high-purity $\left(>18 \mathrm{M} \Omega \mathrm{cm}^{-1}\right)$ deionized water and acidified with $\mathrm{HNO}_{3}$ Suprapur (Merck) to $0.2 \%$. For performance control of the atomic absorption spectrometer, a certified multielement standard was used (Spectrascant Certified, Teknolab). The quality-assurance and quality-control criteria were satisfied when the measured parameter of the standard reference material (Loam-B, catalog no. CRM-LO-B; High-Purity Standard, USA) and the quality-control sample (a previously characterized soil sample with a known concentration of metals) differed by no more than $5 \%$. Available N, P, K contents were determined according to Sadzawka et al. [46].

To assess the chemical evolution of substrates under different treatments, $35 \mathrm{~mL}$ of pore-water samples were taken from each experimental substrate using Rhizon soil porewater samplers (Rhizosphere Research Products, Wageningen, The Netherlands), following the method described in
Vulkan et al. [47]. Substrate pore-water samples were kept in acid-washed polyethylene plastic vials $(50 \mathrm{~mL})$, and then a subsample was acidified with $\mathrm{HNO}_{3}$ suprapur (Merck) and analyzed for total dissolved $\mathrm{Cu}$ (method SW-486 of US EPA [45]) by Inductively Coupled Plasma-Mass Spectrometry (ICP-MS; Perkin Elmer ELAN6100 with auto sampler). The other subsample was acidified with $\mathrm{H}_{3} \mathrm{PO}_{3}$ suprapur (Merck) and analyzed for dissolved organic carbon (DOC; method 415.1 of US EPA [48]), using an Apollo 9000 TOC analyzer (Tekmar-Dohrmann, USA).

2.3.2. Microbial Analysis. Substrate aliquots for microbial analysis were kept in hermetically sealed plastic bags, as collected in the field, and stored at $4^{\circ} \mathrm{C}$ in the dark until their microbiological analysis. Basal respiration was determined by placing $50 \mathrm{~g}$ of each substrate sample at $70 \%$ of field capacity in a $0.5 \mathrm{~L}$ air-tight sealed jar along with $10 \mathrm{~mL}$ of $1 \mathrm{~N} \mathrm{NaOH}$, followed by incubation for 28 days in the dark at $28^{\circ} \mathrm{C}$. The $\mathrm{C}-\mathrm{CO}_{2}$ evolution was periodically determined by titration [49]. Basal respiration rate was calculated based on cumulative $\mathrm{CO}_{2}$ evolution over the 28 days period. Microbial biomass $\mathrm{C}(\mathrm{MBC})$ was determined by the chloroform fumigation extraction method [50]. This parameter results from the difference between fumigated and nonfumigated samples, corrected with the $K_{E C}$ value of 0.45 [51]. The microbial metabolic quotient was calculated as basal respiration $\left(\mu \mathrm{g} \mathrm{C}-\mathrm{CO}_{2} \mathrm{~h}^{-1}\right)$ per mg of microbial biomass $\mathrm{C}$ according to Anderson and Domsch [52].

2.4. Plant Sampling and Analysis. Aboveground plant biomass was determined at each experimental plot by clipping vegetation at ground level in three randomly placed quadrats $\left(0.35 \mathrm{~m} \times 0.35 \mathrm{~m}\right.$ or $\left.0.12 \mathrm{~m}^{2}\right)$ by the end of September 2006 and 2008, after seed production in grasses and at the mid growing season of herbs. Plant biomass of each experimental plot was harvested, placed in a preweighed paper bag, and transported to the laboratory where they were washed with tap water and deionized water in order to eliminate external contamination. Shoots were then dried in a forced air oven at $60^{\circ} \mathrm{C}$ and weighed after $3 \mathrm{~d}$ to obtain the aerial dry biomass. Plant tissues were ground to powder in an agate ball mill and digested with $\mathrm{HNO}_{3}-\mathrm{HF}-\mathrm{H}_{2} \mathrm{O}_{2}$ in a microwave oven (Milestone 1200; Milestone Microwave System, Monroe, Conn, USA). Copper content in shoots was determined by ICP-MS (Perkin Elmer ELAN 6100 with 
TABle 3: Texture of experimental substrates (bulk) at the time of establishment of the field assay (year 1, 2006), at a depth of 0-20 cm. Codes of treatments follow Table 1.

\begin{tabular}{|c|c|c|c|c|c|}
\hline \multirow{2}{*}{ Treatment } & \multicolumn{3}{|c|}{ Texture $(\%)$} & \multirow{2}{*}{ Texture type* } & \multirow{2}{*}{$\begin{array}{c}\text { Particles }>2,000 \mu \mathrm{m} \\
(\%)\end{array}$} \\
\hline & $<2 \mu \mathrm{m}$ & $2 \mu \mathrm{m}-50 \mu \mathrm{m}$ & $50 \mu \mathrm{m}-2,000 \mu \mathrm{m}$ & & \\
\hline $\mathrm{C}$ & 14 & 42 & 44 & Loam & 11 \\
\hline $\mathrm{RM}$ & 13 & 33 & 54 & Loam & 39 \\
\hline RMS & 12 & 25 & 63 & Sandy loam & 39 \\
\hline $\mathrm{B} 1$ & 12 & 43 & 45 & Loam & 21 \\
\hline B2 & 20 & 43 & 37 & Loam & 38 \\
\hline G1 & 16 & 44 & 40 & Loam & 15 \\
\hline G2 & 19 & 40 & 41 & Loam & 19 \\
\hline $\mathrm{O} 1$ & 9 & 37 & 54 & Loam & 8 \\
\hline $\mathrm{O} 2$ & 11 & 30 & 59 & Sandy Loam & 18 \\
\hline GB & 21 & 42 & 37 & Loam & 15 \\
\hline GM & 15 & 37 & 47 & Loam & 20 \\
\hline $\mathrm{OB}$ & 11 & 50 & 39 & Silt Loam & 19 \\
\hline $\mathrm{OM}$ & 18 & 40 & 42 & Loam & 17 \\
\hline
\end{tabular}

* According to the soil textural classification chart of the US Department of Agriculture.

an auto sampler) according to methods SW-486 [45]. Every digestion batch included one blank sample, one SRM sample (1573a tomato leaves; National Institute of Standards and Technology, Gaithersburg, Md, USA), one duplicate sample, and one quality-control sample for the quality-assurance and quality-control criteria. The quality-assurance and qualitycontrol criteria were satisfied when the measured parameter of the standard reference material (1573a tomato leaves) and the quality-control sample differed by no more than $5 \%$.

2.5. Statistical Analysis. Significance of plant and microbial response variables due to experimental treatments were tested by one- (treatment) or two-way (treatment and time) analysis of variance followed by the LSD Fisher test when required. Normality and homogeneity of variances were checked with the Shapiro-Wilks and Levene tests, respectively; logarithmic transformations were used when required. Simple lineal regressions and Pearson's correlation analyses were used to determine correlations among variables (i.e., substrates). Statistical analyses were conducted using the software InfoStat [53].

\section{Results}

3.1. Substrate Properties. Tailings at the experimental site have loam texture, according to the soil textural classification of the USDA (Table 3). In general, addition of amendments, either alone or in mixtures, did not modify the percentage of particle size distribution below $2,000 \mu \mathrm{m}$, hence maintaining the loam texture. Exceptions were RMS, O2, and $\mathrm{OB}$ treatments (Table 3); RMS treatment had the same sandy loam texture of pure sediments, as they were applied at the soil surface without incorporation. Slight changes in soil texture detected in the other two treatments (O2 and $\mathrm{OB})$ may be only explained by typical variations of tailings texture [7]. When the coarse fraction is considered $(>2,000 \mu \mathrm{m})$, higher percentages (among 1.4 to 3.5 times higher) are, in general, found for amended tailings when compared to control tailings (Table 3). Increases were higher for B than for $\mathrm{G}$ and $\mathrm{O}$, and they showed to be dose dependent, as most of the OM incorporated into experimental plots was retained on the sieve. As expected, the highest values of coarse particle fraction $(>2,000 \mu \mathrm{m})$ were found on plots where rubble from $\mathrm{Cu}$-lixiviation piles was incorporated (Table 3), as this material has $68 \%$ of particles $>2,000 \mu \mathrm{m}$.

At the beginning of the assay (year 1 or 2006), addition of amendments improved most chemical (i.e., CEC, SOC, and DOC) and nutritional (i.e., N, P) properties of tailings (Tables 3 and 4). Biosolids and grape residues, either alone or mixed with other materials, produced the more marked changes in chemical and nutritional properties of tailings, particularly in terms of CEC, SOC, and available N-P$\mathrm{K}$ concentrations, when compared to control (Table 4). Olive residues mainly improved SOC of tailings in a dosedependent form (Table 4). However, all organic amendments contained soluble salts, and their addition into tailings increased EC with respect to control $\left(5.3 \mathrm{mS} \mathrm{cm}^{-1}\right)$, up to $26.4 \mathrm{mS} \mathrm{cm}^{-1}$, particularly when applied in high doses; this effect was more pronounced with biosolids (Table 4) but also occurred after addition of high dosages $\left(200 \mathrm{tha}^{-1}\right)$ of grape and olive residues.

The carbon to nitrogen ratio largely varied among treatments and generally decreased with addition of organic amendments, particularly in the case of biosolids and manure as these are N-rich materials (Table 4). Incorporation of amendments into tailings did not change or slightly reduced total $\mathrm{Cu}$ concentrations in the substrate, thus having no or minor dilution effects. The exception was treatment G2 with addition of $200 \mathrm{tha}^{-1}$ of grape residues which reduced 1.8 times total $\mathrm{Cu}$ (Table 4 ). The $\mathrm{pH}$ of substrates only varied from slightly to moderately alkaline values, in the range of 7.40 to 8.20 , and it almost did not vary with time (Table 4).

By the end of the experiment (year 3 or 2008), CEC, SOC, available N-P-K, and C:N ratio markedly decreased 
TABLE 4: Evolution of chemical properties of experimental substrates (bulk) from the time of establishment of the field assay (year 1, 2006) and after 2 years (year 3, 2008), at a depth of $0-20 \mathrm{~cm}$. Codes of treatments follow Table 1.

\begin{tabular}{|c|c|c|c|c|c|c|c|c|c|c|c|c|c|c|c|c|c|c|}
\hline \multirow[t]{2}{*}{ Treatment } & \multicolumn{2}{|c|}{$\mathrm{pH}$} & \multicolumn{2}{|c|}{$\begin{array}{c}\mathrm{EC} \\
\left(\mathrm{mS} \mathrm{cm}^{-1}\right)\end{array}$} & \multicolumn{2}{|c|}{$\begin{array}{c}\text { CEC } \\
\left(\mathrm{meq} 100 \mathrm{~g}^{-1}\right)\end{array}$} & \multicolumn{2}{|c|}{$\begin{array}{l}\text { SOC } \\
(\%)\end{array}$} & \multicolumn{2}{|c|}{$\begin{array}{c}\mathrm{N}_{\text {available }} \\
\left(\mathrm{mg} \mathrm{kg}^{-1}\right)\end{array}$} & \multicolumn{2}{|c|}{$\begin{array}{c}\mathrm{P}_{\text {available }} \\
\left(\mathrm{mg} \mathrm{kg}^{-1}\right)\end{array}$} & \multicolumn{2}{|c|}{$\begin{array}{c}\mathrm{K}_{\text {available }} \\
\left(\mathrm{mg} \mathrm{kg}^{-1}\right)\end{array}$} & \multicolumn{2}{|c|}{$\mathrm{C}: \mathrm{N}$ ratio } & \multicolumn{2}{|c|}{$\begin{array}{l}\text { Total Cu } \\
\left(\mathrm{mg} \mathrm{kg}^{-1}\right)\end{array}$} \\
\hline & Y 1 & Y3 & Y 1 & Y3 & Y 1 & Y3 & Y 1 & Y3 & Y 1 & Y3 & Y 1 & $\mathrm{Y} 3$ & Y 1 & Y3 & Y 1 & Y3 & Y 1 & Y3 \\
\hline C & 8.0 & 8.0 & 5.3 & 7.4 & 3,7 & 5.8 & 2.0 & 0.7 & 9 & Bdl & 8 & 8 & 142 & 73 & 56.6 & 6.7 & 6248 & 6140 \\
\hline $\mathrm{RM}$ & 7.6 & 7.9 & 9.1 & 11.9 & 18,1 & 7.8 & 3.3 & 1.5 & 14 & 13 & 139 & 53 & 2821 & 826 & 12.7 & 7.9 & 6445 & 6604 \\
\hline RMS & 7.4 & 7.8 & 5.9 & 6.9 & 21,5 & 9.7 & 2.6 & 1.2 & 35 & 11 & 42 & 25 & 469 & 269 & 18.7 & 9.0 & 4910 & 5728 \\
\hline B1 & 8.1 & 8.0 & 13.5 & 15.0 & 9,3 & 4.9 & 2.0 & 1.1 & 480 & 425 & 287 & 47 & 616 & 232 & 10.8 & 4.3 & 4655 & 5876 \\
\hline B2 & 7.8 & 7.7 & 26.4 & 19.6 & 31,5 & 7.0 & 5.0 & 1.3 & 984 & 814 & 993 & 87 & 2127 & 404 & 6.4 & 4.9 & 4013 & 4839 \\
\hline G1 & 8.2 & 7.9 & 8.9 & 7.5 & 12,6 & 4.9 & 2.5 & 1.4 & 24 & 9 & 54 & 13 & 1264 & 155 & 48.3 & 9.1 & 6506 & 6879 \\
\hline G2 & 7.6 & 8.0 & 12.0 & 8.9 & 24,0 & 8.2 & 3.4 & 2.0 & 180 & 6 & 269 & 40 & 4727 & 422 & 8.5 & 7.3 & 3394 & 5208 \\
\hline O1 & 8.1 & 8.0 & 8.5 & 6.5 & 6,5 & 5.8 & 2.4 & 1.1 & 5 & Bdl & 15 & 8 & 713 & 81 & 28.3 & 14.4 & 8588 & 7369 \\
\hline $\mathrm{O} 2$ & 7.8 & 8.0 & 10.2 & 7.9 & 8,4 & 5.6 & 5.8 & 1.6 & 26 & Bdl & 16 & 8 & 1464 & 188 & 37.3 & 12.8 & 6739 & 5215 \\
\hline GB & 8.0 & 8.1 & 12.0 & 9.3 & 15,5 & 4.5 & 3.3 & 1.3 & 444 & 32 & 269 & 41 & 1850 & 295 & 21.2 & 9.1 & 7163 & 5928 \\
\hline GM & 8.2 & 8.0 & 13.1 & 8.7 & 23,6 & 6.3 & 4.8 & 1.7 & 207 & 22 & 175 & 33 & 3088 & 333 & 91.8 & 7.4 & 7391 & 7353 \\
\hline $\mathrm{OB}$ & 7.8 & 8.0 & 9.7 & 6.6 & 7,3 & 10.0 & 4.4 & 1.5 & 178 & Bdl & 77 & 16 & 885 & 102 & 23.4 & 12.6 & 5856 & 6178 \\
\hline OM & 8.0 & 8.2 & 14.5 & 10.8 & 36,5 & 8.0 & 5.1 & 1.1 & 24 & Bdl & 84 & 20 & 3055 & 512 & 19.9 & 6.4 & 5857 & 5317 \\
\hline
\end{tabular}

Y1: year 1; Y3: year 3; EC: electrical conductivity; CEC: cation exchange capacity; SOC: soil organic carbon; Bld: below detection limit.

TABLE 5: Evolution of the concentration of dissolved organic carbon (DOC) and total dissolved $\mathrm{Cu}$ in the pore water of substrates from the time of establishment of the field assay (year 1 or 2006) and after 2 years (year 3 or 2008). Codes of treatments follow Table 1.

\begin{tabular}{lcccc}
\hline \multirow{2}{*}{ Treatment } & \multicolumn{2}{c}{ DOC $\left(\mathrm{mg} \mathrm{L}^{-1}\right)$} & \multicolumn{2}{c}{$\mathrm{Cu}\left(\mathrm{mg} \mathrm{L}^{-1}\right)$} \\
& Y1 & Y3 & Y1 & Y3 \\
\hline C & 11 & 29 & 0.04 & 0.17 \\
RM & 542 & 795 & 4.52 & 0.06 \\
RMS & 218 & 148 & 1.22 & 4.01 \\
B1 & 2412 & 274 & 29.12 & 0.57 \\
B2 & 3048 & 600 & 116.92 & 1.13 \\
G1 & 202 & 72 & 2.81 & 0.11 \\
G2 & 523 & 113 & 8.24 & 0.05 \\
O1 & 310 & 57 & 0.69 & 0.65 \\
O2 & 831 & 138 & 2.28 & 0.51 \\
GB & 516 & 253 & 5.63 & 1.24 \\
GM & 780 & 190 & 7.79 & 1.00 \\
OB & 813 & 243 & 28.04 & 0.40 \\
OM & 918 & 165 & 6.96 & 2.44 \\
\hline
\end{tabular}

Y1: year 1; Y3: year 3 .

in all treatments, but in all cases values were higher than control plots (Table 4). Even though available $\mathrm{N}$ tended to decrease with time, minor reductions were detected on biosolids-amended plots when compared to other organic amendments (Table 4). Total $\mathrm{Cu}$ concentrations in the substrate did not show relevant variations with time while EC values either slightly decreased or increased with time (Table 4).

Dissolved organic carbon in pore water was very low in tailings (control plots), but it increased by 1 to 2 orders of magnitude with incorporation of amendments (Table 5).
Specifically, DOC reached highest values in those plots where only biosolids were added (B1 and B2). In general, DOC values decreased with time, but they were more marked in some treatments, such as B1 and B2 (Table 5). Total dissolved Cu in pore water of substrates increased from 17 to 2,923 times with addition of amendments when compared to control plots (Table 5). Biosolids amended plots showed the higher increases reaching concentrations of 29.1 and $116.9 \mathrm{mg} \mathrm{L}^{-1}$ in treatments B1 and B2, respectively (Table 5). However, Cu concentrations in pore water markedly decreased with time, reaching values quite alike among treatments after three years (Table 5). During the first year of the study, a positive and significant relation between DOC and total dissolved $\mathrm{Cu}$ in pore water was found $\left(R^{2}=0.75, P<0.05\right)$, but by the third year this relation was not significant $\left(R^{2}=0.01, P<0.73\right)$.

3.2. Plant Responses. Figure 1 shows the variation of aerial plant biomass (dry weight basis, d.w.) among experimental treatments with time, while Table 6 shows variation of $\mathrm{Cu}$ content in shoots. A two-way ANOVA for aerial plant biomass indicated significant differences among experimental treatments $(F=7.08, P<0.05)$, year since amendments addition $(F=51.07, P<0.05)$, and the interaction among these factors $(F=7.46, P<0.05)$. Control plots showed very low aerial biomass production ( 4.5 to $5 \mathrm{~g} \mathrm{~m}^{-2}$ dry weight basis (d.w.)), irrespective of the year (Figure 1). During the first growing season, aerial plant biomass strongly varied among treatments, being higher on treatments RMS and G1 (19 and $11 \mathrm{~g} \mathrm{~m}^{-2}$ d.w., resp.) and null or very limited on treatments with addition of biosolids ( 0 to $0.3 \mathrm{~g} \mathrm{~m}^{-2} \mathrm{~d}$.w.; Figure 1); all other treatments showed an aerial biomass production that ranged from 2.5 to $7.8 \mathrm{~g} \mathrm{~m}^{-2} \mathrm{~d}$.w. Plant biomass tended to increase with time on most treatments (Figure 1). However, after three years, the highest increase in aerial plant biomass production occurred on treatment 
TABLE 6: Evolution of the concentration of copper in aerial plant biomass (mean \pm standard deviation, $n=3$ ) from the time of establishment of the field assay (year 1 or 2006) and after 2 years (year 3 or 2008). Codes of treatments follow Table 1. Values followed by the same letter are not significantly different at $P<0.05$ according to a two-way ANOVA and LSD Fisher test.

\begin{tabular}{lcc}
\hline Treatment & \multicolumn{2}{c}{ Cu in shoot $\left(\mathrm{mg} \mathrm{kg}^{-1}\right)$} \\
\hline C & $237 \pm 120.3^{\mathrm{abc}}$ & Y3 \\
RM & $310 \pm 215.7^{\mathrm{bcd}}$ & $203 \pm 19.6^{\mathrm{abc}}$ \\
RMS & $90 \pm 8.3^{\mathrm{a}}$ & $270 \pm 433.4^{\mathrm{cde}}$ \\
B1 & $826 \pm 480.6^{\mathrm{f}}$ & $207 \pm 90.5^{\mathrm{abc}}$ \\
B2 & - & $144 \pm 40.9^{\mathrm{ab}}$ \\
G1 & $189 \pm 69.8^{\mathrm{abc}}$ & $345 \pm 268.8^{\mathrm{bcde}}$ \\
G2 & $231 \pm 114.9^{\mathrm{abc}}$ & $187 \pm 48.4^{\mathrm{abc}}$ \\
O1 & $559 \pm 428.9^{\mathrm{e}}$ & - \\
O2 & $507 \pm 493.2^{\mathrm{de}}$ & $280 \pm 202.4^{\mathrm{bc}}$ \\
GB & $427 \pm 274.4^{\mathrm{de}}$ & $154 \pm 31.5^{\mathrm{ab}}$ \\
GM & $316 \pm 293.3^{\mathrm{bcde}}$ & $180 \pm 35.4^{\mathrm{abc}}$ \\
OB & $235 \pm 104.9^{\mathrm{abc}}$ & $207 \pm 94.2^{\mathrm{abc}}$ \\
OM & $275 \pm 83.4^{\mathrm{bcd}}$ & $312 \pm 162.8^{\mathrm{bcde}}$ \\
\hline
\end{tabular}

Y1: year 1; Y3: year 3 .

TABle 7: Evolution of metabolic quotient (mean \pm standard deviation, $n=3)$ in experimental substrates $(0-20 \mathrm{~cm})$ from the time of establishment of the field assay (year 1 or 2006) and after 2 years (year 3 or 2008). Codes of treatments follow Table 1. Values in the same column followed by the same letter are not significantly different at $P<0.05$ according to ANOVA.

\begin{tabular}{|c|c|c|}
\hline \multirow{2}{*}{ Treatment } & \multicolumn{2}{|c|}{ Metabolic quotient $\left(\mu \mathrm{g} \mathrm{C}-\mathrm{CO}_{2} \mathrm{mg} \mathrm{Cbio}^{-1} \mathrm{~h}^{-1}\right)$} \\
\hline & $\mathrm{Y} 1$ & $\mathrm{Y} 3$ \\
\hline $\mathrm{C}$ & $5.0 \pm 0.75^{\mathrm{a}}$ & $4.0 \pm 0.83^{\mathrm{a}}$ \\
\hline $\mathrm{RM}$ & $3.0 \pm 0.50^{\mathrm{b}}$ & $2.0 \pm 0.62^{\mathrm{b}}$ \\
\hline RMS & $3.0 \pm 0.35^{\mathrm{b}}$ & $1.6 \pm 0.71^{\mathrm{b}}$ \\
\hline B1 & $6.9 \pm 0.68^{c}$ & $0.6 \pm 0.51^{\mathrm{c}}$ \\
\hline B2 & $7.5 \pm 0.71^{\mathrm{d}}$ & $0.9 \pm 0.77^{\mathrm{c}}$ \\
\hline G1 & $3.2 \pm 0.51^{b}$ & $2.8 \pm 0.68^{\mathrm{d}}$ \\
\hline G2 & $3.4 \pm 0.65^{\mathrm{b}}$ & $1.2 \pm 0.80^{\mathrm{bc}}$ \\
\hline $\mathrm{O} 1$ & $7.1 \pm 0.92^{c}$ & $4.7 \pm 1.03^{\mathrm{a}}$ \\
\hline $\mathrm{O} 2$ & $7.5 \pm 1.09^{\mathrm{d}}$ & $4.8 \pm 0.92^{\mathrm{a}}$ \\
\hline GB & $3.9 \pm 0.71^{b c}$ & $1.6 \pm 0.73^{b}$ \\
\hline GM & $3.7 \pm 0.78^{\mathrm{bc}}$ & $1.2 \pm 0.50^{\mathrm{bc}}$ \\
\hline $\mathrm{OB}$ & $3.6 \pm 0.80^{\mathrm{b}}$ & $1.8 \pm 0.62^{\mathrm{b}}$ \\
\hline $\mathrm{OM}$ & $4.7 \pm 0.85^{\mathrm{ab}}$ & $2.9 \pm 0.75^{b}$ \\
\hline
\end{tabular}

Y1: year 1; Y3: year 3; Cbio: microbial biomass C.

B1 $\left(480 \mathrm{~g} \mathrm{~m}^{-2}\right.$, d.w.), followed by treatments B2 $\left(283 \mathrm{~g} \mathrm{~m}^{-2}\right.$ d.w.) and RM (112 $\mathrm{g} \mathrm{m}^{-2}$ d.w.). On the contrary, treatments $\mathrm{O} 1$ and $\mathrm{O} 2$, with addition of olive residues had marked reductions in aerial production, reaching values of only 0.1 to $0.2 \mathrm{~g} \mathrm{~m}^{-2}$ d.w. (Figure 1 ).

A two-way ANOVA for $\mathrm{Cu}$ concentration in shoots indicated significant differences among experimental treatments $(F=2.33, P<0.05)$, year since amendments addition

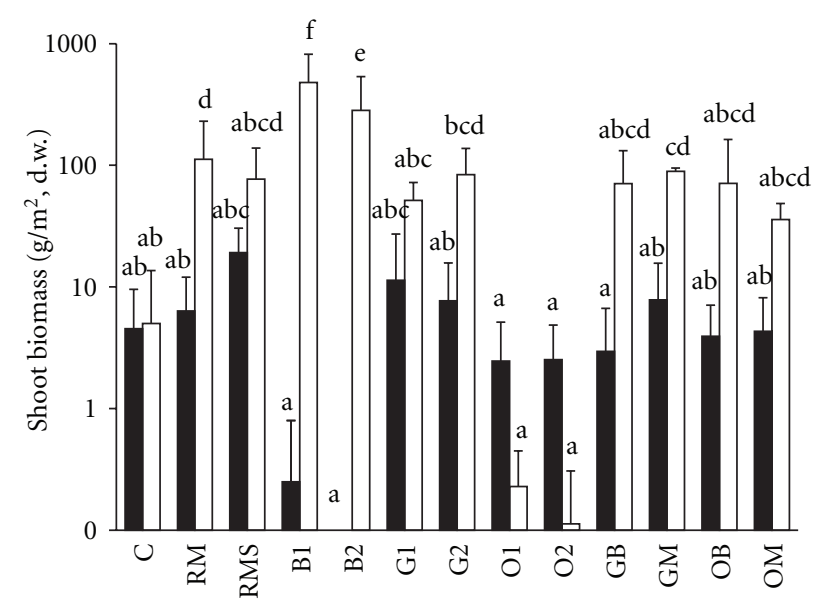

FIGURE 1: Evolution of plant aerial biomass (dry weight basis: d.w.; $\log 10$ scale) in experimental treatments (mean \pm standard deviation, $n=3$ ) from the time of establishment of the field assay (year 1 or 2006 in black columns) and after 2 years (year 3 or 2008 in white columns). Codes of treatments follow Table 1. Same letters indicate no significant differences at $P<0.05$ according to a twoway ANOVA and LSD Fisher test.

$(F=7.34, P<0.05)$, and the interaction among these factors $(F=3.52, P<0.05)$. Plants in control plots reached mean values of $203-237 \mathrm{mg} \mathrm{Cu} \mathrm{kg}^{-1}$ in aerial tissues with no significant variation among years (Table 6). During the first year, all other treatments did not show significant differences in $\mathrm{Cu}$ concentrations in shoots (i.e., RM, RMS, G1, G2, OB, OM) or showed significant increases (B1, O1, $\mathrm{O} 2, \mathrm{~GB}$ ) when compared to control plots. The maximum $\mathrm{Cu}$ concentrations in shoots occurred in treatment $\mathrm{B} 1$ $\left(826 \mathrm{mg} \mathrm{Cu} \mathrm{kg}^{-1}\right.$ ), followed by treatments O1, O2, and GB that showed values that ranged from 427 to $559 \mathrm{mg} \mathrm{kg}^{-1}$. In most treatments, $\mathrm{Cu}$ contents in shoots remained the same or significantly decreased with time (Table 6). Specifically, $\mathrm{Cu}$ contents in shoots of plants in treatments B1, O2, and GB were reduced from 2 to 4 times with time (Table 6). With the exception of control and treatments with olive residues addition (O1 and $\mathrm{O} 2)$, no visual metal toxicity symptoms (i.e., redness and chlorotic leaves, stunted plants) were, however, detected on field plants. Furthermore, biomass production increased with time in most treatments as shown above (Figure 1), with exception of control and treatments with olive residues, thus indicating no metal phytotoxicity of most amended substrates.

3.3. Microbiological Properties. Results of microbiological parameters are given in Figure 2 (accumulated basal respiration), Figure 3 (biomass C), and Table 7 (metabolic quotient). Values of both microbial basal respiration (MBR; Figure 2) and microbial biomass C (MBC; Figure 3) were low and constant in time in control plots, while the metabolic quotient (Table 7) was higher and constant in time in control plots when compared to experimental treatments.

Two-way ANOVAs for MBR and MBC indicated in both cases significant differences among experimental treatments, 
TABle 8: Tables of two-way analysis of variance for microbial accumulated basal respiration and microbial biomass C (mean \pm standard deviation, $n=3)$ in experimental substrates $(0-20 \mathrm{~cm})$ from the time of establishment of the field assay (year 1 or 2006$)$ and after 2 years (year 3 or 2008).

\begin{tabular}{|c|c|c|c|c|c|}
\hline Parameter & Source of variation & Degrees of freedom & Mean squares & $\mathrm{F}$ & $P$ \\
\hline \multirow[t]{5}{*}{ Basal respiration } & Model & 25 & 105727 & 152.2 & $<0.01$ \\
\hline & Treatment & 12 & 57253 & 82.4 & $<0.01$ \\
\hline & Year & 1 & 1352296 & 1947.2 & $<0.01$ \\
\hline & Treatment $\times$ Year & 12 & 50320 & 72.5 & $<0.01$ \\
\hline & Error & 52 & 695 & & \\
\hline \multirow[t]{5}{*}{ Biomass C } & Model & 25 & 55094 & 253.9 & $<0.01$ \\
\hline & Treatment & 12 & 23278 & 107.3 & $<0.01$ \\
\hline & Year & 1 & 819816 & 3779.4 & $<0.01$ \\
\hline & Treatment $\times$ Year & 12 & 23183 & 106.9 & $<0.01$ \\
\hline & Error & 52 & 217 & & \\
\hline
\end{tabular}

TABle 9: Pearson's correlation coefficients between plant aerial biomass and several microbial and chemical (bulk and pore water) properties of experimental substrates $(n=39)$.

\begin{tabular}{lc}
\hline Variable & Plant aerial biomass \\
\hline DOC & -0.20 \\
SOC & 0.54 \\
EC & 0.47 \\
Microbial basal respiration & 0.55 \\
Metabolic quotient & -0.65 \\
Cu concentration in pore water & 0.51 \\
Microbial biomass C & 0.60 \\
Cu concentration in shoots & -0.42 \\
\hline
\end{tabular}

DOC: dissolved organic carbon; SOC: soil organic carbon; EC: electric conductivity.

year since amendments addition, and the interaction among these factors (Table 8). At the beginning of the assay (year 1 or 2006), both MBR and MBC significantly increased with addition of all amendments (Figures 2 and 3). Increase in MBR was higher in treatments RM, G2, OB, and OM (from 16 to 32 times) and lower in treatment $\mathrm{O} 1$ (5 times) with respect to control. In the case of $\mathrm{MBC}$, increase was higher in treatments G2, OB, B2, and RMS (from 24 to 32 times) with respect to control; furthermore, for both parameters and all organic amendments used ( $B, G, O)$, the increase was dose dependent. MBR and MBC tended to decreased with time in all treatments, MBR showing more marked reductions than MBC (Figures 2 and 3). After three years, BMR values of all treatments reached values similar to control plots, with the exception of treatment GM that showed values 2 times higher than control plots (Figure 2). In the case of $\mathrm{MBC}$, even though this parameter decreased in time to values similar to control plots, treatments $\mathrm{B} 2, \mathrm{O} 1$, and $\mathrm{O} 2$ remained significantly higher than control plots, reaching values up to 3.5 times higher than control (Figure 3). A significant simple lineal regression existed among $\mathrm{MBR}$ and $\mathrm{MBC}\left(R^{2}=0.37\right.$, $F=21.7, P<0.05)$ during the first year of the assay, but this disappeared after three years $(R 2=0.09, F=3.8, P=$ 0.0577 ) of experimentation. Finally, the metabolic quotient

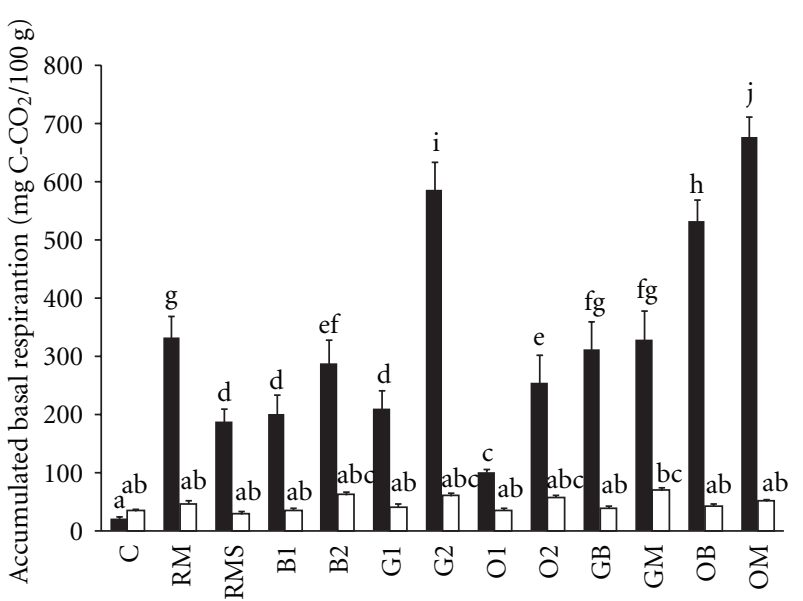

FIGURE 2: Evolution of accumulated basal respiration (28 days; mean \pm standard deviation, $n=3$ ) in experimental substrates from the time of establishment of the field assay (year 1 or 2006 in black columns) and after 2 years (year 3 or 2008 in white columns). Codes of treatments follow Table 1. Same letters indicate no significant differences at $P<0.05$ according to a two-way ANOVA and LSD Fisher test.

tended to decrease with time (Table 7). The highest values were recorded in treatments $\mathrm{O} 1$ and $\mathrm{O} 2$ for both years of evaluation. Treatments B1 and B2 showed high values in year 1 , similar to treatments $\mathrm{O} 1$ and $\mathrm{O} 2$, but markedly decreased on the following years, reaching the lowest values in year 3 (Table 7).

\subsection{Correlation between Biological and Chemical Parameters} of Substrates. Pearson's correlations between all soil properties (bulk and pore water) and plant-related parameters were calculated. The most relevant are shown in Table 9. The strength of the associations was interpreted according to the Hopkins' correlation classification [54]: insubstantial (0.0-0.1), low (0.1-0.3), moderate (0.3-0.5), high (0.5-0.7), very high $(0.7-0.9)$, and nearly perfect $(0.9-1.0)$. Correlation analysis of plant aerial biomass showed high positive relationship with SOC, MBR, and $\mathrm{Cu}$ concentration in pore 


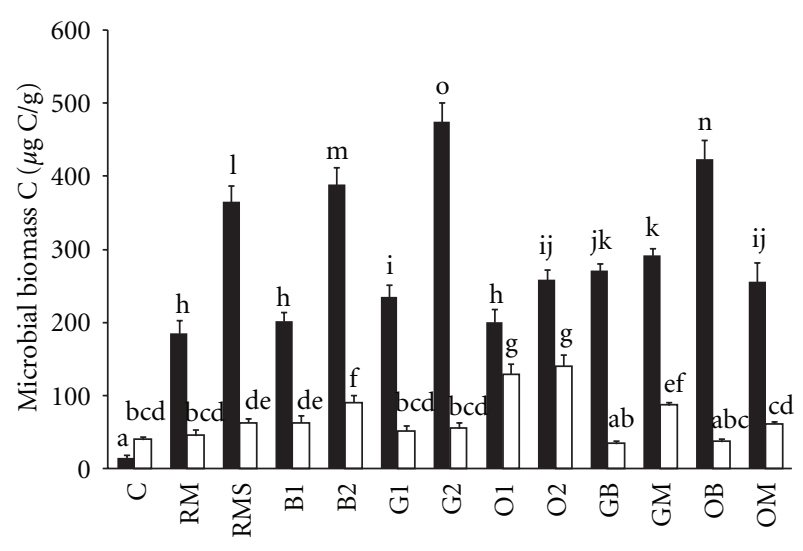

FIGURE 3: Evolution of microbial biomass carbon (MBC; mean \pm standard deviation, $n=3$ ) in experimental substrates from the time of establishment of the field assay (year 1 or 2006 in black columns) and after 2 years (year 3 or 2008 in white columns). Codes of treatments follow Table 1. Same letters indicate no significant differences at $P<0.05$ according to a two-way ANOVA and LSD Fisher test.

water; a very high negative relationship with metabolic quotient; a very high positive relationship with MBC; a moderate negative relationship with $\mathrm{Cu}$ concentration in shoots.

\section{Discussion}

4.1. Substrates Properties. Soils are generally classified as saline when they have EC values higher than $4 \mathrm{mS} \mathrm{cm}^{-1}$ [55]. Under this guideline, all treatments were moderately to strongly saline, even after three years since establishment, and even though organic amendments were incorporated into tailings (mixed). Secondary salinisation of substrates, due to application of organic residues, can be a major constraint in aided phytostabilization strategies, particularly under semiarid environments where evapotranspiration exceeds infiltration of water due to scarce rain events (e.g., [56]). For example, Lombard et al. [37] found that a composted biosolid-treated calcareous soil increased EC by 21 and $41 \%$ above the control soil when applied at rates of only $14 \mathrm{tha}^{-1}$ and $44.5 \mathrm{tha}^{-1}$, respectively, in an area with semiarid climate. The increase in EC was expected because biosolids are high in complex mixtures of soluble salts [37]. Salinisation of tailings (increased EC) by amendments may be limiting for plant establishment and growth, but it would be compensated by high CEC of organic amendments (with the exception of olive residues) and discarded rubble from lixiviation piles. In semiarid climates, salinity is usually combined with high soil $\mathrm{pH}$ (alkalinity), because of $\mathrm{CaCO}_{3}$ enrichment in the uppermost soil layers; hence calcareous soils are common; in the case of the experimental area, $\mathrm{pH}$ of substrates only ranged from slightly to moderately alkaline, but $\mathrm{Ca}$ content of tailings is high (1.5\%). Although the effect of $\mathrm{pH}$ on the activity of soil microorganisms has been reported [57, 58], variations in soil $\mathrm{pH}$ in the present study do not seem to be sufficiently great to establish differences in the biological activity since no correlation between $\mathrm{MBC}$ and $\mathrm{pH}$ was found.

The average SOC in mine tailings of semiarid areas of north-central Chile is only about $0.23 \%$ [39]. This might predict low or lack of microbiological activity. Indeed, indigenous microbial communities associated with mine tailings often show limited density and diversity, relative to undisturbed sites $[11,59]$, and mainly correspond to iron-/sulfur-oxidizing bacteria [12]. However, SOC reached a value of $2 \%$ in La Cocinera TSF. Most of the SOC in tailings probably comes from flotation reagents used for the copper concentration process in the flotation plant. The level of SOC of all organically amended tailings increased noticeably with respect to control during the first year, in agreement with literature (i.e., [31]), but it decreased along the third year of the experiment, probably due to mineralization of easily degradable materials added [60]; however, in all cases, it remained above that of control plots and thus assuring microbial activity and plant growth. This may be also attributed to the presence of the plant cover developed after amendments application, with organic inputs such as root exudates and plant remains compensating $\mathrm{C}$ losses through mineralization, and due to the exhaustion of the labile organic $\mathrm{C}$ and the increase of the recalcitrant fraction of $\mathrm{C}$, which is less prone to mineralization [61, 62]. For example, Müller da Silva et al. [27] found beneficial changes in ecosystem functioning, such as enhanced biological cycling of nutrients, in Eucalyptus plantations where biosolids were incorporated into degraded soils; as a result of increased plant biomass production, due to improved OM and nutrient soil levels, higher transfers of these components to the litter and subsequently to the soil were measured; if litter degradation is adequate, then selfsustainability of the system may be reached with no need of further additions of amendments, particularly for plant formations adapted to nutrient-poor soils like in semiarid areas. Furthermore, the slow release of nutrients contained within the biosolids and other organic amendments, when compared to chemical fertilizers [63], makes it possible to restore soil nutrient stocks throughout the development cycle of revegetated areas. Longer-term evaluations of the experimental plots established in the present study, in terms of $\mathrm{OM}$ and nutrients cycling among other parameters, are thus required for better conclusions.

Addition of organic amendments decreased $\mathrm{C}: \mathrm{N}$ ratio of tailings, hence improving fertility of substrate; however, a large variation in this parameter existed among treatments, as locally available organic amendments have different $\mathrm{N}$ concentrations. For example, biosolids have large $\mathrm{N}$ concentrations $(7.4 \%)$, while grape and olive residues have much lower concentrations $(2.9 \%$ and $1 \%$, resp.). Variations in $\mathrm{C}: \mathrm{N}$ ratio determine different effects on microbiological processes and therefore in $\mathrm{N}$ availability to plants, not only in the short term but also in the long term (i.e., [24, 64]). For example, the decrease of this ratio to recommended values of 20 to 30 means that $\mathrm{N}$ is mineralized and thus available for soil microorganisms and plant roots [65]. However, very low $(<20) \mathrm{C}: \mathrm{N}$ ratios may generate excessive $\mathrm{N}$ mineralization with consequent lixiviation of nitrates to groundwater and 
release of ammonia $[27,66]$ and $\mathrm{CO}_{2}$ to the atmosphere [67], thus restricting seed germination and early stages of plant development $[27,66]$. This effect may have occurred on biosolids-amended tailings, particularly when elevate doses were applied (treatment B2), as no seed germination was observed during the first year (data not given). On the other hand, elevated values of this ratio $(>30)$ indicate low $\mathrm{N}$ concentrations, which is a less favorable condition for soil microbial activity and plant development; this last situation is further limiting if the main $\mathrm{C}$ forms of the material are recalcitrant (i.e., lignin), which is resistant to microbial degradation [68]. In this case, $\mathrm{N}$ is sequestered into soil microorganisms and not available for plant root uptake [69]. For example, addition of olive residues resulted in elevated $\mathrm{C}: \mathrm{N}$ rates $(>28)$, and it remained high after three years. A shortage of $\mathrm{N}$, due to the low content of this element in olive residues, may have occurred after three years thus explaining the marked reduction in aerial biomass production under these treatments (O1 and $\mathrm{O} 2$ ); mixture of olive residues with other N-rich materials, such as biosolids and goat manure, allowed longer-term $\mathrm{N}$ availability, and thus sustained aerial plant biomass production in time should be possible without further additions to maintain adequate fertility.

The organic amendments increased the initial level of DOC, an effect which was still present at the third year but with much reduced concentrations. The high content of low molecular weight organic acids in biosolids and olive residues at dressing time, such as fulvic acids, may pose a metal toxicity risk for plants due to their capability for increasing metal solubility and bioavailability in the substrate solution (e.g., [31, 32, 70, 71]). Metal cations, such as $\mathrm{Cu}^{2+}$, are complexed by DOC, and these soluble organometallic complexes can be readily absorbed by plant roots [31, 32, 72-75] and/or leached into deep substrate layers [76]. Indeed, higher copper contents have been detected in shoots of grasses and some trees growing on biosolids-mixed tailings [25] and soils [31, 32, 77]. This phenomenon was detected in the present study in both biosolids and olive residues amended tailings, particularly during the first year. A decrease in the concentration of soluble metals would be expected on the longer term, as detected in the present study, once the mineralization of labile organic matter in biosolids or other organic materials leads to stabilized organic matter, as it has been shown by Al-Wabel et al. [78].

4.2. Biological Properties. The establishment of a vegetation cover on mine tailings located in semiarid Mediterranean climates is fundamental to protect these sites against erosive processes and for in situ immobilization of metals in the substrate; at the same time, it contributes to increase the soil organic matter content. In addition, a plant cover and particularly, the builtup of plant rhizosphere will influence the biological quality of the substrate by favoring the soil microbial activity and phytostabilization of these sites. On the other hand, soil microbiota is a key component to assure nutrient cycling for plant availability and long-term sustainability.
Application of amendments on mine tailings under semiarid Mediterranean climatic conditions improved the biological properties of original substrate. Organic amendments also favored plant growth which protect substrate from natural forces (i.e., wind and rain) and contribute to phytostabilization. The species used in the present study were able to survive in the tailings, but growth measured as dry aerial biomass largely varied among treatments. Biosolids inhibited seed germination (data not shown) and showed to be limiting for plant establishment and growth at the beginning of the assay, irrespective of application dose (100 and $200 \mathrm{tha}^{-1}$ ). This may be result of the high salinity of this material, but also due to the large concentration of DOC which mobilized $\mathrm{Cu}$ into soil pore water thus posing $\mathrm{Cu}$ toxicity risks to plants. However, at the end of the assay, these treatments showed the highest plant yields, maybe as a result of salt and DOC leaching through the profile due to irrigation and natural precipitation, as it has been shown in other field studies where biosolids were used as organic amendments for mine tailings (e.g., $[25,56])$. Furthermore, temporal changes in $\mathrm{C}: \mathrm{N}$ ratio of organic-amended tailings may also affect plant establishment and productivity as demonstrated by Brown et al. [64]. They demonstrated that increasing the $\mathrm{C}: \mathrm{N}$ ratio of organic amendments added to mine tailings to $\geq 20$ : 1 increased plant species richness and growth, thus affecting native plant restoration.

Olive residues allowed plant establishment but they were inadequate for sustained plant growth, showing poor yield of biomass after three years; however, they improved microbial properties (MSR and MBC) of tailings even after three years since plot establishment. One explanation of this result may be based on the presence of phenolic compounds, which are toxic $[79,80]$. The organic matter of olive residues mainly consists of oil, polysaccharides, sugars, polyphenols, polyalcohols, proteins, organic acids (i.e., acetic and formic acid), phenols, lipids, and tannins, some of them known to be toxic to plants [70] or biorecalcitrant [79, 81]. However, inorganic constituents at the concentration levels found in olive residues are not toxic. In fact, it has been proved that they may potentially act as a good source of plant nutrients [82-84]. According to this, the use of composted olive residues is suggested as when olive residues undergo through a proper biodegradation process, like composting, the toxic organic compounds are broken down, and remaining components of these residues are suitable as good source of plant and microbial nutrients [84]. Other explanation may be the low $\mathrm{N}$ fertility of this material as discussed above, as when olive residues were mixed with biosolids and goat manure (N-rich sources), plant biomass increased 59\% with respect to control. Thus it is not advisable to apply directly olive residues to mine tailings for phytostabilization. Several treatments showed to be adequate for plant establishment and growth in the short term, besides of improving microbiological properties of tailings (e.g., RM, B1, B2, OB). These treatments showed the highest biomass yield, MSR, and MBC; however, plots have to be evaluated in the longer term for better conclusions.

The negative correlation between $\mathrm{qCO}_{2}$ and plant aerial biomass found in the present study reflects environmental 
stress probably as a result of phytotoxicity effects from some organic amendments mentioned above, like olive residues and biosolids. Treatments which had the higher plant biomass yield showed the lower $\mathrm{qCO}_{2}$ values. On the other hand, a positive correlation was found between $\mathrm{MBC}$ and plant aerial biomass, confirming the usefulness of $\mathrm{MBC}$ as an indicator of changes in vegetation. These results suggest that $\mathrm{qCO}_{2}$ and $\mathrm{MBC}$ constitute sensitive indicators of plant growth and thus for phytostabilization progress [85]. The present study showed that herbaceous/grass species can grow in a wide range of metal concentrations $(\mathrm{Cu}, \mathrm{Zn}$, and $\mathrm{Fe}$ ) in mine tailings. Zinc and $\mathrm{Cu}$ are essential for normal plant growth and development at low concentrations [86] and play important roles in several metabolic processes in plants. However, excess $\mathrm{Cu}$ and $\mathrm{Zn}$ in soil may retard plant growth [87, 88]. Kabata-Pendias and Pendias [89] reported that total fractions in soil equal to 70 to $400 \mathrm{mg} \mathrm{kg}^{-1}$ of $\mathrm{Zn}$ and 60 to $125 \mathrm{mg} \mathrm{kg}^{-1}$ of $\mathrm{Cu}$ are toxic to plants. The metal contents in the substrates studied greatly exceeded these ranges.

With regard to metal accumulation in shoots, it has been stated in the literature that organic amendments that contain a high proportion of humified OM (i.e., compost) can decrease the mobility of some metals due to the formation of stable chelates [90, 91]. However, the residues used in the present study were not stabilized at the beginning of the assay, and the humified OM could have been low, as shown by elevated DOC levels in pore water. Instead, they might facilitate metal transport in substrate by acting as carriers through formation of metal-organic complexes [92], at least in the short term. As a result, $\mathrm{Cu}$ contents in shoots were alike or slightly higher than in control plots. However, the concentration of metals in shoots tended to decrease with time in most treatments, suggesting that an immobilization process is taking place, probably because of organic matter $(\mathrm{OM})$ stabilization. Shoot copper concentrations found in all treatments were well above critical concentrations described in plants and the maximum tolerable level in animals [88, 89, 93]. Nevertheless, it is important to state some relevant aspects. First, critical concentrations of copper have been defined for sensitive plants, normally represented by crops and vegetables (i.e., $[88,89,93]$ ); in the present study, local adapted plants were used, which may be more tolerant to elevated copper levels in aerial tissues. Second, some researchers have reported that part of the metals found in shoots might be adhered onto stem and leaves surface and are not absorbed into the internal structures of the plant, suggesting that total metal content in shoots is overestimated (e.g. [87, 94, 95]). This external contamination may exist even after standard washing protocols, particularly in xerophytic plants of semiarid environments as trichomes and glands are common morphological structures on leaves adapted to drought (i.e., [96]). Finally, the maximum tolerable level of copper in animals assumes that animal has no other feed or forage source, which is not the case, because these sites are not destined for grazing. Thus, the high concentration of copper in shoots reported in the present study does not necessarily imply risk for food webs.

\section{Conclusions}

Aided phytostabilization based on the use of local amendments and plant sources is a feasible field-scale technology for large-scale postoperative $\mathrm{Cu}$-sulfidic mine TSF under semiarid Mediterranean climate conditions. A broad range of organic- and hard-rock mine wastes showed to be adequate for improving chemical and biological properties of tailings. However, selection of adequate local available amendments and management options for long-term release of limiting conditions of tailings for microbial and plant establishment and development are key aspects.

Biosolids, grape residues, and goat manure, either alone or in mixtures, are adequate organic materials for improving chemical and biological properties of tailings; however, high doses should be avoided ( $\geq 200$ ton ha ${ }^{-1}$ d.w.), particularly in the case of biosolids, as salinization, ammonia volatilization, and $\mathrm{Cu}$ mobilization into pore water may secondary occur with consequent limiting conditions for plant establishment. Even though biosolids are useful organic amendments to speed up the builtup of plant biomass and restore microbial properties of $\mathrm{Cu}$-sulfidic mine tailings, lixiviation of excess salts and DOC during early stages of aided phytostabilization is required in order to get proper plant establishment and growth.

Olive residues are adequate materials for restoring microbial properties of tailings, but their low $\mathrm{N}$ fertility and high content of phytotoxic compounds made it inadequate to sustain plant development in the long term. Their mixture with $\mathrm{N}$-rich materials, such as biosolids and manure, would be a better management option for these applications; furthermore, preliminary composting may be another alternative, particularly to eliminate the compounds responsible of phytotoxicity, but this needs to be further evaluated.

Discarded rubble from copper-oxide lixiviation piles can be a useful amendment for tailings, but it needs to be mixed with organic amendments (i.e., manure) to assure microbial inoculation of tailings and improvement of nutritional properties that may limit plant establishment and grow. Furthermore, general chemical characteristics of rubble and tailings where it will be incorporated should be first evaluated in order to determine its efficacy and define specific management options (i.e., $\mathrm{pH}$ management).

Local grass/herb species are appropriate for aided phytostabilization of abandoned and postoperative TSF under semiarid Mediterranean climate conditions, as they rapidly build up a continuous plant cover, but high $\mathrm{Cu}$ concentrations found in shoots may increase the potential risk of metal transfer to the food chain, an aspect that should be further evaluated, considering background metal contents in wild plants.

\section{Acknowledgments}

The present study was funded by the Innova Chile CORFO project 04CR9IXD-01 to R. Ginocchio. The authors would like to acknowledge the permanent support of Mr. Marcos Velásquez, mining engineer of Planta Ovalle, ENAMI, Ismael 
Jiménez and Jaime Cuevas of INIA Intihuasi with the establishment and maintenance of the field assay.

\section{References}

[1] A. D. Bradshaw, "The reconstruction of ecosystems," Journal of Applied Ecology, vol. 20, no. 1, pp. 1-17, 1983.

[2] J. McCall, J. Gunn, and H. Struik, "Photo interpretive study of recovery of damaged lands near the metal smelters of Sudbury, Canada," Water, Air, and Soil Pollution, vol. 85, no. 2, pp. 847$852,1995$.

[3] R. Badilla-Ohlbaum, R. Ginocchio, P. H. Rodríguez et al., "Relationship between soil copper content and copper content of selected crop plants in central Chile," Environmental Toxicology and Chemistry, vol. 20, no. 12, pp. 2749-2757, 2001.

[4] R. Ginocchio, P. Sánchez, L. M. de la Fuente et al., "Agricultural soils spiked with copper mine wastes and copper concentrate: implications for copper bioavailability and bioaccumulation," Environmental Toxicology and Chemistry, vol. 25, no. 3, pp. 712-718, 2006.

[5] M. O. Mendez and R. M. Maier, "Phytoremediation of mine tailings in temperate and arid environments," Reviews in Environmental Science and Biotechnology, vol. 7, no. 1, pp. 4759, 2008.

[6] R. Ginocchio, L. M. de la Fuente, P. Sánchez et al., "Soil acidification as a confounding factor on metal phytotoxicity in soils spiked with copper-rich mine wastes," Environmental Toxicology and Chemistry, vol. 28, no. 10, pp. 2069-2081, 2009.

[7] B. Dold and L. Fontboté, "Element cycling and secondary mineralogy in porphyry copper tailings as a function of climate, primary mineralogy, and mineral processing," Journal of Geochemical Exploration, vol. 74, no. 1-3, pp. 3-55, 2001.

[8] R. Ginocchio, "Effects of a copper smelter on a grassland community in the Puchuncaví Valley, Chile," Chemosphere, vol. 41, no. 1-2, pp. 15-23, 2000.

[9] R. Ginocchio, P. H. Rodríguez, R. Badilla-Ohlbaum, H. E. Allen, and G. E. Lagos, "Effect of soil copper content and $\mathrm{pH}$ on copper uptake of selected vegetables grown under controlled conditions," Environmental Toxicology and Chemistry, vol. 21, no. 8, pp. 1736-1744, 2002.

[10] I. G. Petrisor, D. Dobrota, K. Komnitsas, I. Lazar, J. M. Kuperberg, and M. Serban, "Artificial inoculation-perspectives in tailings phytostabilization," International Journal of Phytoremediation, vol. 1, no. 1, pp. 1-15, 2004.

[11] R. de la Iglesia, D. Castro, R. Ginocchio, D. van der Lelie, and B. González, "Factors influencing the composition of bacterial communities found at abandoned copper-tailings dumps," Journal of Applied Microbiology, vol. 100, no. 3, pp. 537-544, 2006.

[12] N. Diaby, B. Dold, H. R. Pfeifer, C. Holliger, D. B. Johnson, and K. B. Hallberg, "Microbial communities in a porphyry copper tailings impoundment and their impact on the geochemical dynamics of the mine waste," Environmental Microbiology, vol. 9, no. 2, pp. 298-307, 2007.

[13] F. F. Munshower, Practical Handbook of Disturbed Land Revegetation, Lewis Publisher, Boca Raton, Fla, USA, 1993.

[14] W. Krzaklewski and M. Pietrzykowski, "Selected physicochemical properties of zinc and lead ore tailings and their biological stabilisation," Water, Air, and Soil Pollution, vol. 141, no. 1-4, pp. 125-142, 2002.

[15] R. Ginocchio, C. Santibáñez, P. León-Lobos, S. Brown, and A. J. M. Baker, "Sustainable rehabilitation of copper mine tailings in Chile through phytostabilization: more than plants," in
Proceedings of the 2nd International Seminar on Mine Closure, A. Fourie, M. Tibbet, and J. Wiertz, Eds., pp. 465-474, Australian Centre for Geomechanics, Santiago, Chile, 2007.

[16] Z. H. Ye, Z. Y. Yang, G. Y. S. Chan, and M. H. Wong, "Growth response of Sesbania rostrata and S. cannabina to sludge-amended lead/zinc mine tailings. A greenhouse study," Environment International, vol. 26, no. 5-6, pp. 449-455, 2001.

[17] Z. Y. Yang, J. G. Yuan, G. R. Xin, H. T. Chang, and M. H. Wong, "Germination, growth, and nodulation of Sesbania rostrata grown in $\mathrm{Pb} / \mathrm{Zn}$ mine tailings," Environmental Management, vol. 21, no. 4, pp. 617-622, 1997.

[18] R. R. Brooks, "Geobotany and hyperaccumulators," in Plants that Hyperaccumulate Heavy Metals: Their Role in Phytoremediation, Microbiology, Archaeology, Mineral Exploration, and Phytomining, R. R. Brooks, Ed., pp. 55-94, CAB International, Wallingford, UK, 1998.

[19] J. Vangronsveld, R. Herzig, N. Weyens et al., "Phytoremediation of contaminated soils and groundwater: lessons from the field," Environmental Science \& Pollution Research, vol. 16, no. 7, pp. 765-794, 2009.

[20] M. Mench, N. Lepp, V. Bert et al., "Successes and limitations of phytotechnologies at field scale: outcomes, assessment and outlook from COST action 859," Journal of Soils and Sediments, vol. 10, no. 6, pp. 1039-1070, 2010.

[21] S. D. Cunningham, W. R. Berti, and J. W. W. Huang, "Phytoremediation of contaminated soils," Trends in Biotechnology, vol. 13, no. 9, pp. 393-397, 1995.

[22] W. W. R. Berti and S. D. Cunningham, "Phytostabilization of metals," in Phytoremediation of Toxic Metals-Using Plants to Clean Up the Environment, I. Raskin and B. D. Ensley, Eds., pp. 71-88, John Wiley \& Sons, New York, NY, USA, 2000.

[23] B. R. Sabey, R. L. Pendleton, and B. L. Webb, "Effect of municipal sewage sludge application on growth of two reclamation shrub species in copper mine spoils," Journal of Environmental Quality, vol. 19, no. 3, pp. 580-586, 1990.

[24] S. L. Brown, C. L. Henry, R. Chaney, H. Compton, and P. S. Devolder, "Using municipal biosolids in combination with other residuals to restore metal-contaminated mining areas," Plant and Soil, vol. 249, no. 1, pp. 203-215, 2003.

[25] C. Verdugo, P. Sánchez, C. Santibáñez et al., "Efficacy of lime, biosolids, and mycorrhiza for the phytostabilization of sulfidic copper tailings in chile: a greenhouse experiment," International Journal of Phytoremediation, vol. 13, no. 2, pp. 107-125, 2011.

[26] S. H. Schoenholtz, H. van Miegroet, and J. A. Burger, "A review of chemical and physical properties as indicators of forest soil quality: challenges and opportunities," Forest Ecology and Management, vol. 138, no. 1-3, pp. 335-356, 2000.

[27] P. H. Müller da Silva, F. Poggiani, and J. P. Laclau, "Applying sewadge sludge to Eucalyptus grandis plantations: effects on biomass production and nutrient cycling through litterfall," Applied and Environmental Soil Science, vol. 2011, Article ID 710614, 11 pages, 2011.

[28] U.S. EPA, "The use of soil amendments for remediation, revitalization, and reusue," EPA 542-R-07-013, Office of Superfund Remediation and Technology Innovation (OSRTI), EPA/National Service Center for Environmental Publications, Cincinnati, Ohio, USA, 2007.

[29] P. Janoš, J. Vávrová, L. Herzogová, and V. Pilařová, “Effects of inorganic and organic amendments on the mobility (leachability) of heavy metals in contaminated soil: a sequential extraction study," Geoderma, vol. 159, no. 3-4, pp. 335-341, 2010. 
[30] A. Lopareva-Pohu, B. Pourrut, C. Waterlot et al., "Assessment of fly ash-aided phytostabilisation of highly contaminated soils after an 8-year field trial-part 1. Influence on soil parameters and metal extractability," Science of the Total Environment, vol. 409, no. 3, pp. 647-654, 2011.

[31] L. A. Junqueira-Teixeira, R. S. Berton, A. R. Coscione, and L. A. Saes, "Biosolids application on banana production: soil chemical properties and plant nutrition," Applied and Environmental Soil Science, vol. 2011, Article ID 238185, 8 pages, 2011.

[32] D. Nash, C. Butler, J. Cody et al., "Effects of biosolids application on pasture and grape vines in south-eastern Australia," Applied and Environmental Soil Science, vol. 2011, Article ID 342916, 11 pages, 2011.

[33] C. Santibáñez, C. Verdugo, and R. Ginocchio, "Phytostabilization of copper mine tailings with biosolids: implications for metal uptake and productivity of Lolium perenne," Science of the Total Environment, vol. 395, no. 1, pp. 1-10, 2008.

[34] W. E. Sopper, Municipal Sludge Use for Land Reclamation, Lewis Publishers, Ann Arbor, Mich, USA, 1993.

[35] K. C. Haering, W. L. Daniels, and S. E. Feagly, "Reclaiming mined lands with biosolids, manures and papermill sludges," in Reclamation of Drastically Disturbed Lands, R. Barnhisel, Ed., pp. 615-644, Soil Science Society of America, Madison, Wis, USA, 2000.

[36] INDAP, Compendio de Información Ambiental, Socioeconómica y Silvoagropecuaria de la IV Región de Coquimbo: Información Para Proyectos de Desarrollo Regional, Universidad de Chile, Centro de Agricultura Ambiente (AGRIMED), INDAPProdecop IV Región, La Serena, Chile, 2001.

[37] K. Lombard, M. O’Neill, A. Ulery et al., "Fly ash and composted biosolids as a source of Fe for hybrid poplar: a greenhouse study," Applied and Environmental Soil Science, vol. 2011, Article ID 475185, 11 pages, 2011.

[38] CIREN, Estudio Agrológico IV Región; Descripciones de Suelos, Materiales y Símbolos, Centro de Información de Recursos Naturales, Santiago, Chile, 2005.

[39] J. F. Casale, R. Ginocchio, and P. León-Lobos, Fitoestabilización de Depósitos de Relaves en Chile. Guía 4: Marco Ambiental y Relaves Mineros Abandonados, Documento Técnico, Centro de Investigación Minera y Metalúrgica e Instituto de Investigaciones Agropecuarias, Santiago, Chile, 2011.

[40] USDA, Survey Laboratory: Methods Manual, Investigations Report No. 42, Version 4.0, United States Department of Agriculture, Washington, DC, USA, 2004.

[41] K. Gold, P. León-Lobos, and M. Way, Manual de Colecta de Semillas de Plantas Silvestres para Conservación y Restauración Ecológica, Instituto de Investigaciones Agropecuarias, Centro Regional de Investigación Intihuasi, La Serena, Chile, 2004, Boletín INIA no. 110.

[42] P. M. Bleeker, A. G. L. Assunção, P. M. Teiga, T. De Koe, and J. A. C. Verkleij, "Revegetation of the acidic, as contaminated Jales mine spoil tips using a combination of spoil amendments and tolerant grasses," The Science of the Total Environment, vol. 300, no. 1-3, pp. 1-13, 2002.

[43] A. D. Bradshaw and M. J. Chadwick, The Restoration of Land. The Ecology and Reclamation of Derelict and Degraded Land, University of California Press, Berkeley, Calif, USA, 1980.

[44] M. Mench, S. Bussière, J. Boisson et al., "Progress in remediation and revegetation of the barren Jales gold mine spoil after in situ treatments," Plant and Soil, vol. 249, no. 1, pp. 187-202, 2003.

[45] U.S. Environmental Protection Agency, Test Methods for Evaluating Solid Waste-Physical/Chemical Methods, Method
SW- 486, Department of Commerce, National Technical Information Service, Springfield, Va, USA, 1997.

[46] A. Sadzawka, M. Carrasco, R. Grez, M. Mora, H. Flores, and A. Neaman, Métodos de Análisis Recomendados para los Suelos de Chile, Instituto de Investigaciones Agropecuárias, Santiago, Chile, 2006.

[47] R. Vulkan, F. J. Zhao, V. Barbosa-Jefferson et al., "Copper speciation and impacts on bacterial biosensors in the pore water of copper-contaminated soils," Environmental Science and Technology, vol. 34, no. 24, pp. 5115-5121, 2000.

[48] U.S. Environmental Protection Agency, "Methods for chemical analysis of water and wastes," EPA 60014-79-020, Washington, DC, USA, 1983.

[49] J. P. E. Anderson, "Soil respiration," in Methods of Soil Analysis, Part 2. Chemical and Microbiological Properties, A. L. Page, Ed., pp. 837-871, Soil Science Society of America, Madison, Wisconsin, USA, 1982.

[50] E. G. Gregorich, G. Wen, R. P. Voroney, and R. G. Kachanoski, "Calibration of a rapid direct chloroform extraction method for measuring soil microbial biomass C," Soil Biology and Biochemistry, vol. 22, no. 7, pp. 1009-1011, 1990.

[51] G. P. Sparling, C. W. Feltham, J. Reynolds, A. W. West, and P. Singleton, "Estimation of soil microbial C by a fumigationextraction method: use on soils of high organic matter content, and a reassessment of the KEC-factor," Soil Biology and Biochemistry, vol. 22, no. 3, pp. 301-307, 1990.

[52] T. H. Anderson and K. H. Domsch, "Application of ecophysiological quotients $\left(\mathrm{qCO}_{2}\right.$ and $\left.\mathrm{qD}\right)$ on microbial biomasses from soils of different cropping histories," Soil Biology and Biochemistry, vol. 22, no. 2, pp. 251-255, 1990.

[53] J. A. D. Rienzo, F. Casanoves, M. G. Balzarini, L. González, M. Tablada, and C. W. Robledo, InfoStat Versión 2009, Grupo InfoStat, FCA, Universidad Nacional de Córdoba, Argentina, 2009.

[54] W. G. Hopkins, "A scale of magnitudes for effect statistics," in A New View of Statistics, Internet Society of Sport Science, 2002, http://www.sportsci.org/resource/stats/effectmag.html.

[55] M. E. Sumner, "Sodic soils: new perspectives," in Australian Sodic Soils: Distribution, Properties and Management, R. Naidu, M. E. Sumner, and P. Rengasamy, Eds., pp. 1-34, CSIRO, Melbourne, Australia, 1995.

[56] S. Brown, A. Svendsen, and C. Henry, "Restoration of high zinc and lead tailings with municipal biosolids and lime: a field study," Journal of Environmental Quality, vol. 38, no. 6, pp. 2189-2197, 2009.

[57] D. N. Rietz and R. J. Haynes, "Effects of irrigation-induced salinity and sodicity on soil microbial activity," Soil Biology and Biochemistry, vol. 35, no. 6, pp. 845-854, 2003.

[58] M. Sardinha, T. Müller, H. Schmeisky, and R. G. Joergensen, "Microbial performance in soils along a salinity gradient under acidic conditions," Applied Soil Ecology, vol. 23, no. 3, pp. 237-244, 2003.

[59] G. Southam and T. J. Beveridge, "Enumeration of Thiobacilli within $\mathrm{pH}$-neutral and acidic mine tailings and their role in the development of secondary mineral soil," Applied and Environmental Microbiology, vol. 58, no. 6, pp. 1904-1912, 1992.

[60] C. Garcia, T. Hernandez, C. Costa, and M. Ayuso, "Evaluation of the maturity of municipal waste compost using simple chemical parameters," Communications in Soil Science and Plant Analysis, vol. 23, no. 13-14, pp. 1501-1512, 1992.

[61] C. A. Campbell and R. P. Zentner, "Soil organic matter as influenced by crop rotations and fertilization," Soil Science Society of America Journal, vol. 57, no. 4, pp. 1034-1040, 1993. 
[62] J. A. Pascual, C. Garcia, T. Hernandez, J. L. Moreno, and M. Ros, "Soil microbial activity as a biomarker of degradation and remediation processes," Soil Biology and Biochemistry, vol. 32, no. 13, pp. 1877-1883, 2000.

[63] C. Graciano, J. F. Goya, M. Arturi, C. Pérez, and J. L. Frangi, "Fertilization in a fourth rotation Eucalyptus grandis plantation with minimal management," Journal of Sustainable Forestry, vol. 26, no. 2, pp. 155-169, 2008.

[64] S. Brown, P. de Volder, H. Compton, and C. Henry, "Effect of amendment $\mathrm{C}: \mathrm{N}$ ratio on plant richness, cover and metal content for acidic $\mathrm{Pb}$ and $\mathrm{Zn}$ mine tailings in Leadville, Colorado," Environmental Pollution, vol. 149, no. 2, pp. 165172, 2007.

[65] Ch. Henry, D. Sullivan, R. Rynk, K. Dorsey, and C. Cogger, Managing Nitrogen from Biosolids, Washington State Department of Ecology, Northwest Biosolids Management Association, Wash, USA, 1999.

[66] D. G. Brockway, D. H. Urie, P. V. Nguyen, and J. B. Hart, "Wastewater and sludge nutrient utilization in forest ecosystems," in The Forest Alternative for Treatment and Utilization of Municipal and Industrial Wastes, D. W. Cole, C. L. Henry, and W. L. Nutter, Eds., pp. 221-245, University of Washington Press, Seattle, Wash, USA, 1986.

[67] P. Faúndez, Actividad Microbiológica Global en Suelos Acondicionados con Biosólidos Cloacales Frescos y Compostados con Residuos Forestales, Universidad de Chile, Facultad de Ciencias Agronómicas, Santiago, Chile, 2005.

[68] T. Gea, A. Artola, X. Sort, and A. Sánchez, "Composting of residuals produced in the catalan wine industry," Compost Science and Utilization, vol. 13, no. 3, pp. 168-174, 2005.

[69] D. Messerer, Sustratos Alternativos en la Propagación de Palto (Persea americana), Universidad Católica de Valparaíso, Facultad de Agronomía, Valparaíso, Chile, 1998.

[70] C. Santibáñez, R. Ginocchio, and M. Teresa Varnero, "Evaluation of nitrate leaching from mine tailings amended with biosolids under Mediterranean type climate conditions," Soil Biology and Biochemistry, vol. 39, no. 6, pp. 1333-1340, 2007.

[71] A. Navarro and F. Martínez, "Effects of sewage sludge application on heavy metal leaching from mine tailings impoundments," Bioresource Technology, vol. 99, no. 16, pp. 7521-7530, 2008.

[72] I. Lamy, S. Bourgeois, and A. Bermond, "Soil cadmium mobility as a consequence of sewage sludge disposal," Journal of Environmental Quality, vol. 22, no. 4, pp. 731-737, 1993.

[73] M. B. McBride, S. Sauvé, and W. Hendershot, "Solubility control of $\mathrm{Cu}, \mathrm{Zn}, \mathrm{Cd}$ and $\mathrm{Pb}$ in contaminated soils," European Journal of Soil Science, vol. 48, no. 2, pp. 337-346, 1997.

[74] V. Antoniadis and B. J. Alloway, "The role of dissolved organic carbon in the mobility of $\mathrm{Cd}, \mathrm{Ni}$ and $\mathrm{Zn}$ in sewage sludgeamended soils," Environmental Pollution, vol. 117, no. 3, pp. 515-521, 2002.

[75] A. S. Coninck and A. Karam, "Impact of organic amendments on aerial biomass production, and phytoavailability and fractionation of copper in a slightly alkaline copper mine tailing," International Journal of Mining, Reclamation and Environment, vol. 22, no. 4, pp. 247-264, 2008.

[76] S. Klitzke and F. Lang, "Hydrophobicity of soil colloids and heavy metal mobilization: effects of drying," Journal of Environmental Quality, vol. 36, no. 4, pp. 1187-1193, 2007.

[77] J. O. Miller, A. D. Karathanasis, and C. J. Matocha, "In situ generated colloid transport of $\mathrm{Cu}$ and $\mathrm{Zn}$ in reclaimed mine soil profiles associated with biosolids application," Applied and Environmental Soil Science, vol. 2011, Article ID 762173, 9 pages, 2011.
[78] M. A. Al-Wabel, D. M. Heil, D. G. Westfall, and K. A. Barbarick, "Solution chemistry influence on metal mobility in biosolids-amended soils," Journal of Environmental Quality, vol. 31, no. 4, pp. 1157-1165, 2002.

[79] F. Cabrera, R. López, A. Martinez-Bordiú, E. De Dupuy Lome, and J. M. Murillo, "Land treatment of olive oil mill wastewater," International Biodeterioration and Biodegradation, vol. 38, no. 3-4, pp. 215-225, 1996.

[80] F. A. El-Gohary, M. I. Badawy, M. A. El-Khateeb, and A. S. El-Kalliny, "Integrated treatment of olive mill wastewater (OMW) by the combination of Fenton's reaction and anaerobic treatment," Journal of Hazardous Materials, vol. 162, no. 2-3, pp. 1536-1541, 2009.

[81] M. Stoller, "On the effect of flocculation as pretreatment process and particle size distribution for membrane fouling reduction," Desalination, vol. 240, no. 1-3, pp. 209-217, 2009.

[82] C. I. Piperidou, C. I. Chaidou, C. D. Stalikas, K. Soulti, G. A. Pilidis, and C. Balis, "Bioremediation of olive oil mill wastewater: chemical alterations induced by Azotobacter vineladii," Journal of Agricultural and Food Chemistry, vol. 48, no. 5, pp. 1941-1948, 2000.

[83] A. Nastri, N. A. Ramieri, R. Abdayem, R. Piccaglia, C. Marzadori, and C. Ciavatta, "Olive pulp and its effluents suitability for soil amendment," Journal of Hazardous Materials, vol. 138, no. 2, pp. 211-217, 2006.

[84] A. A. Zorpas and V. J. Inglezakis, "Integrated applied methodology for the treatment of heavy polluted waste waters from olive oil industries," Applied and Environmental Soil Science, vol. 2011, Article ID 537814, 14 pages, 2011.

[85] S. A. Pavan-Fernandes, W. Bettiol, and C. Clementi-Cerri, "Effect of sewage sludge on microbial biomass, basal respiration, metabolic quotient and soil enzymatic activity," Applied Soil Ecology, vol. 30, no. 1, pp. 65-77, 2005.

[86] M. Lytle, F. W. Lytle, N. Yang et al., "Reduction of Cr(VI) to $\mathrm{Cr}$ (III) by wetland plants: potential for in situ heavy metal detoxification," Environmental Science and Technology, vol. 32, no. 20, pp. 3087-3093, 1998.

[87] A. J. M. Baker and P. L. Walker, "Physiological responses of plants to heavy metals and the quantification of tolerance and toxicity," Chemical Specialization and Bioavailability, vol. 1, pp. 7-17, 1989.

[88] D. C. Adriano, Trace Elements in Terrestrial Environments. Biogeochemistry, Bioavailability, and Risk of Metals, Springer, New York, NY, USA, 2001.

[89] A. Kabata-Pendias and H. Pendias, Trace Element in Soils and Plants, CRC Press LLC, Boca Raton, Fla, USA, 2001.

[90] D. J. Walker, R. Clemente, A. Roig, and M. P. Bernal, "The effects of soil amendments on heavy metal bioavailability in two contaminated Mediterranean soils," Environmental Pollution, vol. 122, no. 2, pp. 303-312, 2003.

[91] R. Clemente, Á. Escolar, and M. P. Bernal, "Heavy metals fractionation and organic matter mineralisation in contaminated calcareous soil amended with organic materials," Bioresource Technology, vol. 97, no. 15, pp. 1894-1901, 2006.

[92] E. J. M. Temminghoff, S. E. A. T. M. van der Zee, and F. A. M. de Haan, "Copper mobility in a copper-contaminated sandy soil as affected by $\mathrm{pH}$ and solid and dissolved organic matter," Environmental Science and Technology, vol. 31, no. 4, pp. 11091115, 1997.

[93] National Research Council, Nutrient Requirements of Domestic Animals, National Academy of Science, National Academy Press, Washington, DC, USA, 7th edition, 1984.

[94] I. González, V. Muena, M. Cisternas, and A. Neaman, "Acumulación de cobre en una comunidad vegetal afectada 
por contaminación minera en el valle de Puchuncaví, Chile central," Revista Chilena de Historia Natural, vol. 81, no. 2, pp. 279-291, 2008.

[95] A. Anic, L. F. Hinojosa, J. Díaz-Forester et al., "Influence of soil chemical variables and altitude on the distribution of highalpine plants: the case of the Andes of central Chile," Arctic, Antarctic, and Alpine Research, vol. 42, no. 2, pp. 152-163, 2010.

[96] A. Fahn and D. F. Cutler, Xerophytes, Gebruder Borntraeger, Berlin, Germany, 1992. 

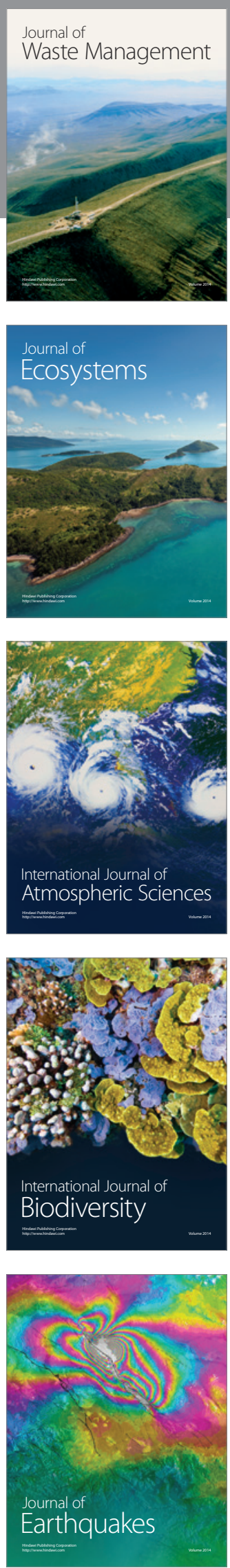
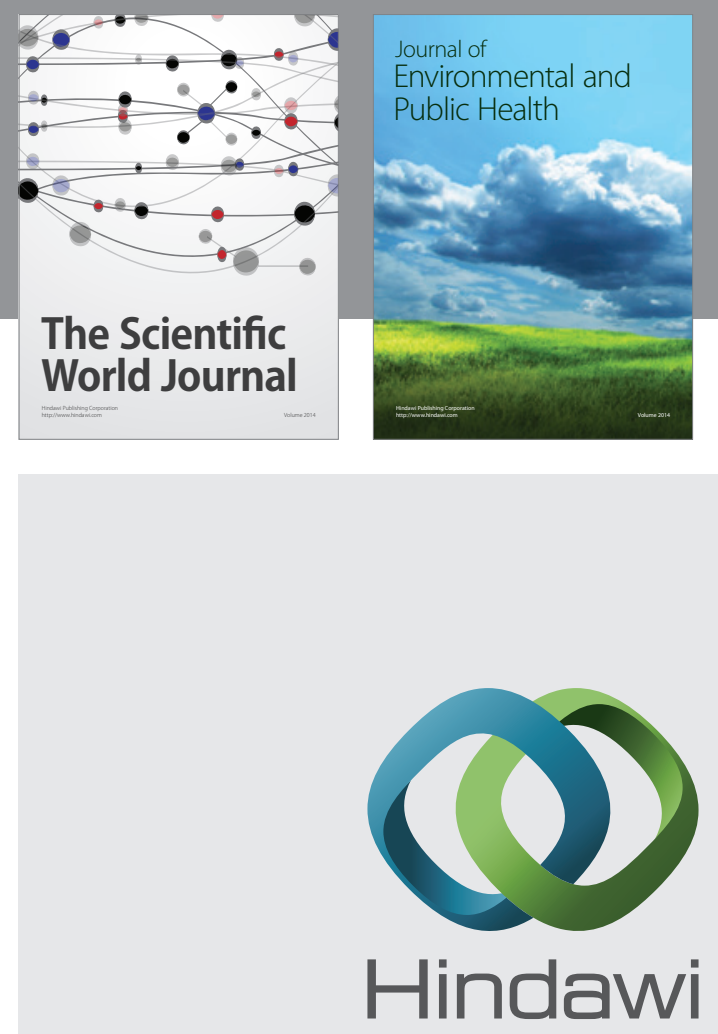

Submit your manuscripts at

http://www.hindawi.com
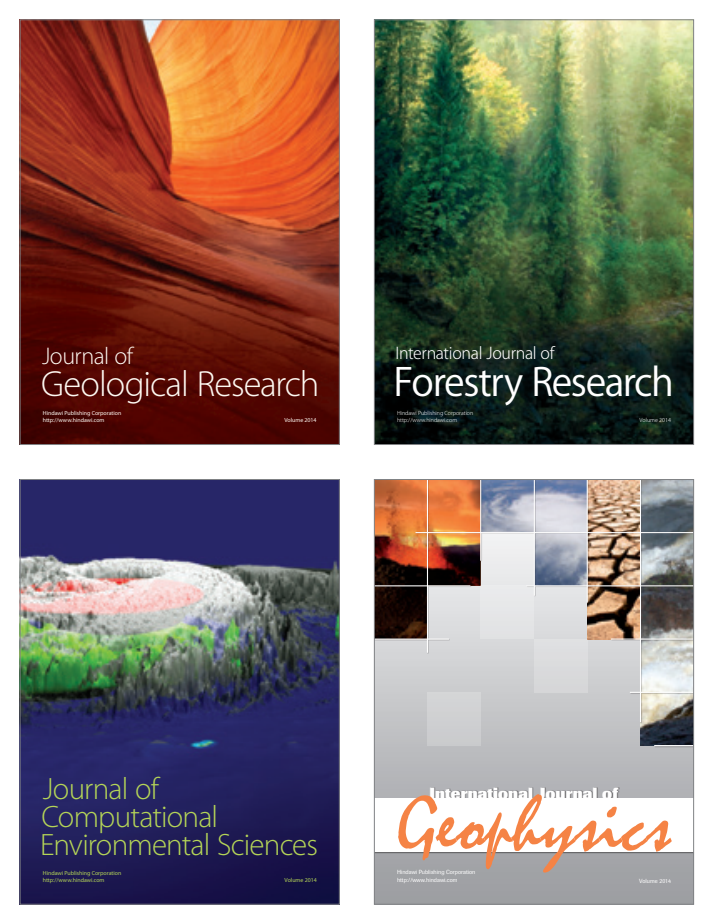
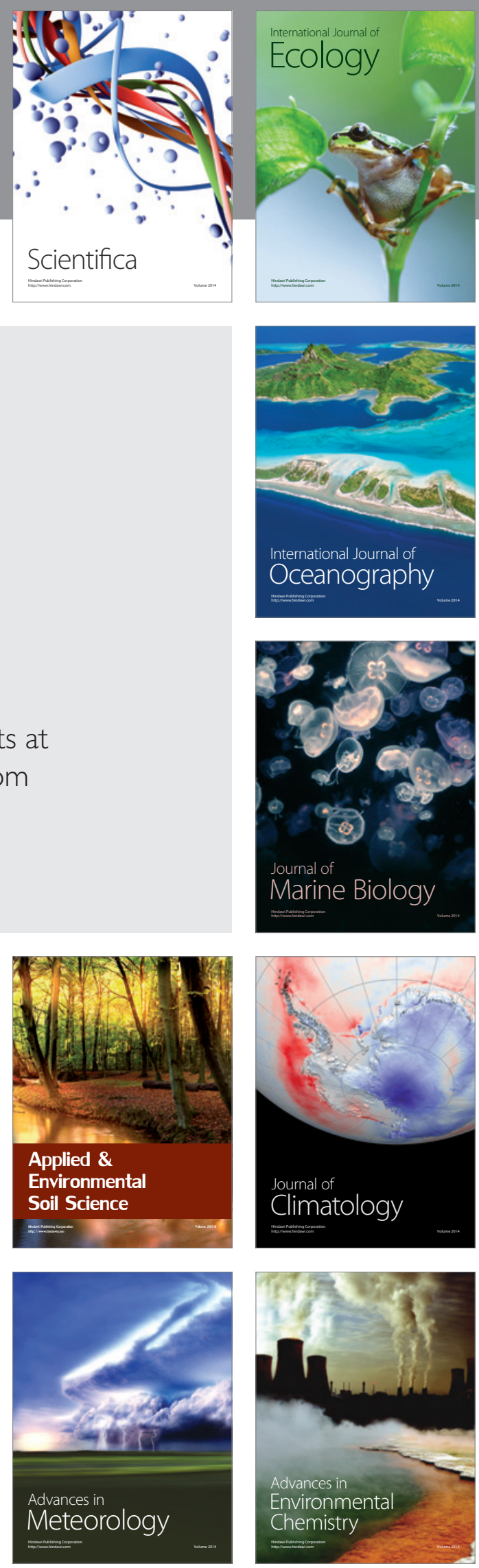